\title{
Acculturative hassles and strategies: Relationship between study abroad related depression, anxiety, and stress
}

\author{
Ching, Gregory S. $\bowtie$
}

Graduate Institute of Educational Leadership and Development, Fu Jen Catholic University, Taiwan, ROC (gregory_ching@yahoo.com; 094478@mail.fju.edu.tw)

\section{Chao, Pei-Ching}

Graduate Institute of Educational Leadership and Development, Fu Jen Catholic University, Taiwan, ROC (126636@mail.fju.edu.tw; 99152513@nccu.edu.tw)

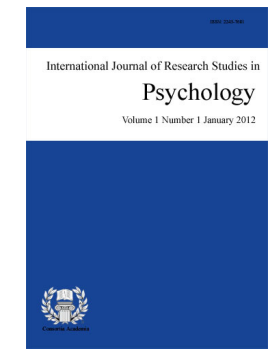

ISSN: 2243-7681 Online ISSN: 2243-769X

OPEN ACCESS Lien, Wei-Chih

Department of Applied Foreign Languages, Lunghwa University of Science and Technology, Taiwan, ROC (wclien@mail.lhu.edu.tw)

Received: 15 May $2014 \quad$ Revised: 20 October $2014 \quad$ Accepted: 9 November 2014 Available Online: 16 November 2014 DOI: $10.5861 /$ ijrsp.2014.818

\section{Abstract}

Within the 2013 OECD annual education report, statistics have shown that there are already around 4.3 million tertiary level students studying outside their home country. Yet, this number is expected to increase in the years to come. However, parallel to the increasing number of study abroad opportunities are the rising number of problematic mental health issues of these international students. In Taiwan, similar trends of increasing number of international students are also observed. A more distinct Taiwan characteristic is the presence of four foreign student groups, namely: international students (IS), mainland Chinese students (MCS), Hong Kong and Macau students (HKM), and the overseas Chinese students (OCS). With the goal of developing Taiwan higher education institutions into strong venues for study abroad, it is quite important that these students are well taken care of. Therefore, understanding the students' mental health situation is a key step in achieving this purpose. In light of this issue, the current paper shall present the findings of a study focusing on the different student groups' acculturative hassles and strategies and the corresponding relationship with their level of depression, anxiety, and stress. Focus group interviews were conducted to gather the various acculturative hassles, while a revised acculturative strategies survey based on Barry's (2001) East Asian Acculturation Measure (EAAM) was used to determine the students' reactions and behaviors during study abroad. In addition, the Depression Anxiety Stress Scales (DASS) was also administered to measure the students' level of depression, anxiety, and stress. A total of 888 responds were collected from an online survey that lasted for three weeks. Factor analyses were accomplished resulting in the formation of three major groups of acculturative hassles, namely: adverse feelings, struggles, and communication (language) difficulties. Statistical results show that the HKM scored highest in the three DASS scales for depression, anxiety, and stress. In addition, OCS is the most marginalized and separated student group among the foreign students. Lastly, IS seems to have the most communication difficulties, while all the students moderately struggles with their academic related hassles. Additional, 
Ching, G. S., Chao, P.-C., \& Lien, W.-C.

implications and recommendations are also provided.

Keywords: study abroad; acculturation strategy; hassle; overseas Chinese students; mainland Chinese students; international students 


\section{Acculturative hassles and strategies: Relationship between study abroad related depression, anxiety, and stress}

\section{Introduction}

Statistics have shown that the number of students studying outside their home countries is but increasing (OECD, 2013). These students more commonly categorized as international (or foreign) students are defined as individuals who temporarily reside in a country other than their country of citizenship in order to participate in international educational exchange as students (Paige, 1990). In Taiwan, it is reported that during the 2013-2014 school year, a total of 78,261 foreign students studied in Taiwan (Ching, Lien, \& Chao, 2014). The Taiwan Ministry of Education (MOE) statistics reports an average annual increase of around $17 \%$ foreign student enrollment. Quite unique is the presence of four distinct foreign student groups, namely: International students (IS), mainland Chinese students (MCS), Hong Kong and Macau students (HKM), and overseas Chinese students (OCS) (MOE, 2014). This influx of foreign students in Taiwan is in line with the drive towards the internationalization of Taiwan higher education institutions (Chin \& Ching, 2009; Ching \& Chin, 2012; Chin, $\mathrm{Wu}$, \& Ching, 2012). More importantly, the impact of low birth rates in Taiwan might also force several low performing universities to close down (Leung, 2013). Therefore, the additional enrolment of foreign students is seen as an opportunity to fill up for the oversupply of higher education institutions and at the same time provides the opportunity to increase its revenue.

Following the recent trend of rising study abroad opportunities are the increasing cases of problematic mental health issues of these sojourning students (Lucas, 2009). Some common reported issues are alienation (Greatrex-White, 2008), binge drinking (Pedersen, Neighbors, Larimer, \& Lee, 2011; Hummer, Pedersen, Mirza, \& LaBrie, 2010; Pedersen, Larimer, \& Lee, 2010), depression (Muto, Hayes, \& Jeffcoat, 2011), loneliness (Hunley, 2010), and many others physical and mental health issues. In reality, study abroad should be an enjoyable experience; even though the encounter with a new culture is not without stress (Berry, 2005; Ward, Bochner, \& Furnham, 2001), however, if signs of mental health issues could be detected early, worst effects of such issues could be prevented. Therefore, it is quite important to understand the mental health situations of these students.

In general, study abroad has well been praised to have produced significant learning improvements, however, two significant obstacles exist; language and culture (Vande Berg, Connor-Linton, \& Paige, 2009). Therefore, successful study abroad can be said to be determined by how, and how well, groups and individuals manage the transition when they come into contact with another culture (Sam \& Berry, 2010, p. 472). Such transition is more commonly known as acculturation. Acculturation explains the process of cultural and psychological change that results following meeting between cultures (Sam \& Berry, 2010, p. 472). Currently, there are several terms interchangeably used with acculturation, such as assimilation, biculturalism, multiculturalism, integration, and globalization, among others (Sam \& Berry, 2006). However, acculturation is still the most common or generic term used by educators and researchers.

Within a study abroad framework, prior to coming into contact with each other, the home (origin) culture and the host (destination) culture are two distinct cultural groups. Acculturating individuals and groups (e.g. foreign students) brings with them cultural and psychological qualities to the new society (host country), and while the new society also possess a variety of such qualities (Sam \& Berry, 2010). Acculturation is then the process of cultural and psychological change that follows such meetings of two distinct cultures. Therefore, to fully understand the compatibility (or incompatibility) in cultural values, norms, attitudes, and personality between the two cultural groups in contact; a careful study on the acculturation process is a must.

Putting it all together, the current paper shall present the findings of a study focusing on the different student 
groups' acculturative hassles and strategies and the corresponding relationship with their level of depression, anxiety, and stress. Focus group interviews were conducted to gather the various acculturative hassles the students encounter, while a revised acculturative strategies survey based on Barry's (2001) East Asian Acculturation Measure (EAAM) was used to determine the students' reactions and behaviors during study abroad. Lastly, the Depression Anxiety Stress Scales (DASS) was also administered to measure the students' level of depression, anxiety, and stress (Lovibond \& Lovibond, 1995). In essence, understanding the inter-relationship among the students' acculturative hassles and strategies and their corresponding level of depression, anxiety, and stress is an important primary step in help making study abroad experience enjoyable and productive.

\section{Research design}

The current study uses a mixed-method research design paradigm, wherein the qualitative focus group interview method was used to collect information needed to help formed a survey questionnaire (Cohen, Manion, \& Morrison, 2007). Later on, the formulated survey was used to gather information at a particular point in time with the notion of describing the existing conditions. For the participants of the study, as mentioned earlier a distinct characteristic of Taiwan higher education institutions' internationalization is the presence of four foreign student groups. Hence, the current study makes use of the four foreign student groups, namely: International students (IS), mainland Chinese students (MCS), Hong Kong and Macau students (HKM), and overseas Chinese students (OCS) as study participants. OCS are students who are of Chinese ethnicity, which are born and still living overseas, or have lived abroad for more than six years and have a permanent residence or have obtained long-term residency in a foreign country. IS are non-Chinese speaking students who are from another country besides mainland China, Hong Kong, Macau, and OCS. HKM are students from Hong Kong and Macau (primarily speaks Cantonese). Lastly, MCS are students from mainland China. Comparative results are then provided to better depict the implications of the various acculturative hassles and strategies towards the different student groups.

\section{The study}

\subsection{Acculturative hassles}

During the fall semester of 2013, an invitation was sent out inviting volunteer study abroad (foreign) students to join a series of focus group discussions within a private university in the Northern area of Taiwan. Free pizzas, sodas, and a convenient store cash certificate worth 100 NTD (approximately 3 USD) were offered as incentive to the participants. Topics of the discussion includes the various hassles that the students' encounter during their daily study (including living) routine in Taiwan. Hassles are said to be the everyday life event dissatisfactions (or distractions), which cause minor stresses (Tajalli, Sobhi, \& Ganbaripanah, 2010).

At the beginning of each session, students are told of the topic and at the same time informed that they can freely leave the session if they are not comfortable with the discussions. The focus group sessions lasted approximately 30 minutes with an average of 6 to 7 attendees. A total of 6 focus group sessions (2 MCS groups, 2 IS groups, 1 HKM group, and 1 OCS group) were accomplished. Average age of participants is 21 years old, while 29 of the students are from the Asia-pacific region with the remaining 11 are from the US and other European countries.

Results of the acculturative hassle focus group sessions were analyzed using the constant comparison approach, wherein newly collected information is compared with previous gathered results (Glaser \& Strauss, 1967). Resulting themes include a 26 items acculturative hassles involving day to day living and academic related activities and a 6 items communication hassles. Further exploratory factor analysis of the items will be discussed in the succeeding sections of this paper. 
Acculturative hassles and strategies: Relationship between study abroad related depression, anxiety, and stress

\subsection{Acculturation strategies}

On many occasions, Berry $(1980,1997,2004,2005)$ mentioned that there are four acculturation strategies based on two distinct orientations towards one's own and to those of the host country. These four strategies are namely: Assimilation, Integration, Separation, and Marginalization. Assimilation includes items that denote the loss of ones' own identity and the fully embracing of the new culture (host country). Integration includes items that describe a person retaining the best of both worlds (home and host countries). Separation includes items that describe ones' reluctant in accepting the new culture, while retaining only ones' own identity. Lastly, marginalization includes items that describe a person who rejects both home and host culture.

To measure the various acculturation strategies, the current study make use of Barry's (2001) 29 items East Asian Acculturation Measure (EAAM). EAAM is specifically designed to gathered data on the four acculturation strategies; more specifically the survey is designed according to the contemporary situations and characteristics of East Asian countries (Yu \& Wang, 2011). Cronbach alpha reliability of the scale is computed to be from .74 to .85 (Barry, 2001). Revisions made on Barry's EAAM are the removal of the items regarding the effects of language. To compensate for the language related items removal, additional emphasis on communication hassles were asked during the previous focus group sessions. In addition, the level of Chinese language proficiencies were also asked and later included in the analysis. Further confirmatory factor analysis of the items will also be discussed in the succeeding sections of this paper.

\subsection{Students' level of depression, anxiety, and stress}

The 42 items Depression Anxiety Stress Scales (DASS) was used to collect the students' self-reported measures of depression, anxiety, and stress. A more distinct note on the DASS is that it was deliberately designed to measure depression, anxiety, and stress within diverse settings (Crawford \& Henry, 2003). The psychometric properties of DASS were assessed with quite high Cronbach alpha reliability of $.91, .84$, and .90 respectively (Lovibond \& Lovibond, 1995). In addition, Lovibond and Lovibond (1995) provided normative scores and standard deviations (SD) for the measures as 6.34 (6.97), 4.7 (4.91), and 10.11 (7.91) for the depression, anxiety, and stress scales, respectively.

\section{Results and discussions}

\subsection{Study participants}

The survey was administered online to all foreign students in Taiwan. A poster was sent and posted in all of the international students' offices throughout Taiwan higher education institutions on December of 2013. As an incentive for all the students who participated in the survey, prizes were given away in a random raffle draw during the middle of December. A total of 888 students participated in the survey. Overall Cronbach's alpha reliability of the survey is computed at .89 , considered to be highly reliable results (Cohen, Manion, \& Morrison, 2007). Table 1 shows that almost half of the participants are IS with 433 or $48.8 \%$, followed by MCS with 270 or $30.4 \%$, OCS with 99 or $11.1 \%$, and lastly HKM with 86 or $9.7 \%$. Table 2 shows a more detailed by country participants separated by gender denoting an almost equal number of male and female respondents.

\section{Table 1}

Student participants categorized by student groups $(N=888)$

\begin{tabular}{|c|c|c|}
\hline Student groups & Frequency & Percent \\
\hline International students (IS) & 433 & 49 \\
\hline Mainland Chinese students (MCS) & 270 & 30 \\
\hline Oversea Chinese students (OCS) & 99 & 11 \\
\hline Hong Kong / Macau students (HKM) & 86 & 10 \\
\hline & 888 & 100 \\
\hline
\end{tabular}


Ching, G. S., Chao, P.-C., \& Lien, W.-C.

Table 2

Study participants' country of origin $(N=888)$

\begin{tabular}{|c|c|c|c|c|}
\hline \multirow{2}{*}{ Country } & \multicolumn{2}{|c|}{ Gender } & \multirow{2}{*}{$n$} & \multirow{2}{*}{$\%$} \\
\hline & Female & Male & & \\
\hline China & 167 & 103 & 270 & 30 \\
\hline Hong Kong & 28 & 26 & 54 & 6 \\
\hline Macau & 15 & 17 & 32 & 4 \\
\hline Indonesia & 52 & 52 & 104 & 12 \\
\hline Malaysia & 47 & 59 & 106 & 12 \\
\hline Vietnam & 26 & 34 & 60 & 7 \\
\hline Singapore & 17 & 9 & 26 & 3 \\
\hline India & 4 & 17 & 21 & 2 \\
\hline US & 7 & 13 & 20 & 2 \\
\hline Philippines & 9 & 8 & 17 & 2 \\
\hline Thailand & 9 & 4 & 13 & 2 \\
\hline Germany & 7 & 5 & 12 & 1 \\
\hline South Korea & 5 & 7 & 12 & 1 \\
\hline France & 7 & 4 & 11 & 1 \\
\hline Japan & 1 & 6 & 7 & 1 \\
\hline Mongolia & 6 & 1 & 7 & 1 \\
\hline Honduras & 2 & 5 & 7 & 1 \\
\hline Gambia & 0 & 6 & 6 & 1 \\
\hline Belize & 2 & 3 & 5 & 1 \\
\hline Nicaragua & 1 & 4 & 5 & 1 \\
\hline Russia & 4 & 1 & 5 & 1 \\
\hline \multirow[t]{2}{*}{ others } & 45 & 43 & 88 & 9 \\
\hline & 461 & 427 & 888 & 100 \\
\hline
\end{tabular}

Note. Average age is 21 years old. Average months of stay $=18$ months.

Average age of students is 21 years old, while the average stay in Taiwan is around 18 mounts. Besides the country of origin, the survey also asked for the participants to provide their level of Chinese language competencies. Table 3 shows that not all of the MCS are fluent with Mandarin Chinese, since some of them might came from regions that have their own dialects. Similar with the HKM students which primarily speaks Cantonese, while the OCS have an even more diverse background wherein most of them considers Mandarin Chinese as their second language.

\section{Table 3}

Participants' Chinese language competency level $(N=888)$

\begin{tabular}{|c|c|c|c|c|c|c|}
\hline Chinese language competency & IS & MCS & OCS & HKM & Frequency & Percent \\
\hline Just started studying & 63 & 0 & 2 & 0 & 65 & 7 \\
\hline Less than 3 months & 31 & 0 & 0 & 1 & 32 & 4 \\
\hline Less than 6 months & 36 & 0 & 1 & 2 & 39 & 4 \\
\hline Less than 1 year & 62 & 0 & 1 & 4 & 67 & 8 \\
\hline More than 1 year & 90 & 3 & 2 & 11 & 106 & 12 \\
\hline More than 3 years & 53 & 6 & 3 & 13 & 75 & 8 \\
\hline More than 5 years & 38 & 50 & 21 & 17 & 126 & 14 \\
\hline Already fluent in Chinese & 60 & 211 & 69 & 38 & 378 & 43 \\
\hline Total & 433 & 270 & 99 & 86 & 888 & 100 \\
\hline
\end{tabular}

\subsection{Acculturative hassles}

To better understand the hidden constructs behind the acculturative hassle survey items, exploratory factor analysis was used to analyze the inter-relationships among the variables (Hair, Black, Babin, Anderson, \& Tatham, 2005). Then after structured equation modelling (SEM) with the help of the software Lisrel was accomplished to further explain the possibility of relationships among the items and latent variables (Schreiber, 
Acculturative hassles and strategies: Relationship between study abroad related depression, anxiety, and stress

Stage, King, Nora, \& Barlow, 2006). Data collected from the survey was encoded and analyzed through the use of the software statistical package for social scientists (SPSS). Data was first screened for univariate outliers and missing data. These were then imputed using the expectation maximization (EM) algorithm of SPSS (Graham, 2009; Weaver \& Maxwell, 2014).

During the factor analysis procedures, a total of 17 items were eliminated from the 32 items acculturative hassle survey. These items were deleted because they did not have a primary factor loading of .50 or above, and no cross-loading of .32 or above (Costello \& Osborne, 2005). Then after, the factorability of the remaining 15 items is tested under several criteria for factor analysis. First, the 15 items were checked for inter-correlation with at least one item of .30 or above. Second, the Kaiser-Meyer-Olkin value was computed to be .90 well above the acceptable value of .50 (Kaiser, 1974). Lastly, the Barlett's test of sphericity was computed to be at 7,639.72 with significant Chi-square $(p<.000)$ and a degrees freedom of 105.

The principal component analysis with varimax rotation was conducted, while the eigenvalues were computed to be greater than 1 (Costello \& Osborne, 2005). Three factors accounting for $67.91 \%$ of the total variances were computed. Each of the factors adverse feeling, struggles, and communication difficulties accounted for $26.51 \%, 24.54 \%$, and $16.85 \%$ of the variance respectively. A scree tests was also computed with the point of inflexion noted in Figure 1, further signifying the number of factors extracted from the items (Catell, 1966). Tables 4 show the various communalities of the items with values of greater than 400 (Worthington \& Whittaker, 2006), together with the Cronbach alpha reliabilities of the factors (.866 to .899; signifying highly reliable results), percent variance, overall means, and means and standard deviations of each of the items. While, Table 5 shows the various factor loading (including the cross-loading) of each of the items.

\section{Table 4}

Acculturative hassle survey items $(N=888)$

\begin{tabular}{|c|c|c|c|}
\hline Factors/Items & Communalities & Mean & $S D$ \\
\hline Adverse feelings $(\alpha=.898,6$ items, $\%$ variance $=26.51)$ & & 1.88 & 0.84 \\
\hline Ha_07. Being alienated by others & .761 & 1.85 & 1.02 \\
\hline Ha_03. Being let down (disappointment) by others & .675 & 1.94 & 1.05 \\
\hline Ha_02. Being isolated by others & .613 & 1.68 & 0.94 \\
\hline Ha_08. Feel of inequality & .674 & 1.94 & 1.11 \\
\hline Ha_09. Being taken advantage by others & .653 & 1.80 & 1.04 \\
\hline Ha_01. Being ignored by others & .628 & 2.08 & 1.05 \\
\hline Struggles $(\alpha=.866,6$ items, $\%$ variance $=24.54)$ & & 2.42 & 0.92 \\
\hline Ha_21. Not having enough time to meet my obligations & .756 & 2.42 & 1.16 \\
\hline Ha_23. Not being able to keep up with assigned tasks & .676 & 2.19 & 1.11 \\
\hline Ha_19. Not being able to concentrate & .706 & 2.30 & 1.12 \\
\hline Ha_20. Not being able to decide about my future career & .557 & 2.51 & 1.28 \\
\hline Ha_22. Not having enough sleep & .500 & 2.71 & 1.28 \\
\hline Ha_26. Not being able to attain expected academic grade & .481 & 2.41 & 1.18 \\
\hline Communication difficulties $(\alpha=.899,3$ items, $\%$ variance $=16.85)$ & & 2.57 & 1.18 \\
\hline La_04. Difficulty in talking about yourself & .850 & 2.39 & 1.33 \\
\hline La_06. Difficulty in understanding jokes/humor & .843 & 2.56 & 1.20 \\
\hline La_05. Difficulty in making yourself understood & .811 & 2.77 & 1.35 \\
\hline
\end{tabular}

Note. Overall $\alpha=.991$, Kaiser-Meyer-Olkin Measure of Sampling Adequacy = .902, Bartlett's Test of Sphericity $=7,639.72, p<.000$, $\mathrm{df}=105$, Total variance $=67.91 \%$

To further validate the acculturative hassle survey, SEM was used. Figure 2 shows the measurement model of the acculturative hassle survey with a Chi-square of 349.71 with $d f=87$, which is significant with $p<.000$ and a root mean square error of approximation (RMSEA) value of .058 all of which are within the acceptable factor analysis values in SEM (Schreiber et al., 2006). Table 6 shows several comparative fit indices (including other indices), such as: Normed Fit Index $(\mathrm{NFI})=.98$, Non-Normed Fit Index $(\mathrm{NNFI})=.98$, Comparative Fit Index $(\mathrm{CFI})=.98$, Incremental Fit Index $(\mathrm{IFI})=.98$, and Relative Fit Index $(\mathrm{RFI})=.97$; all of which are within the acceptable values (Hu \& Bentler, 1999; MacCallum, Browne, \& Sugawara, 1996). Lastly, Table 7 shows the 
Ching, G. S., Chao, P.-C., \& Lien, W.-C.

various standardized and unstandardized coefficients of the models, together with their corresponding $T$ values and measurement errors (Fornell \& Larcker, 1981), further describing fitness of the model.
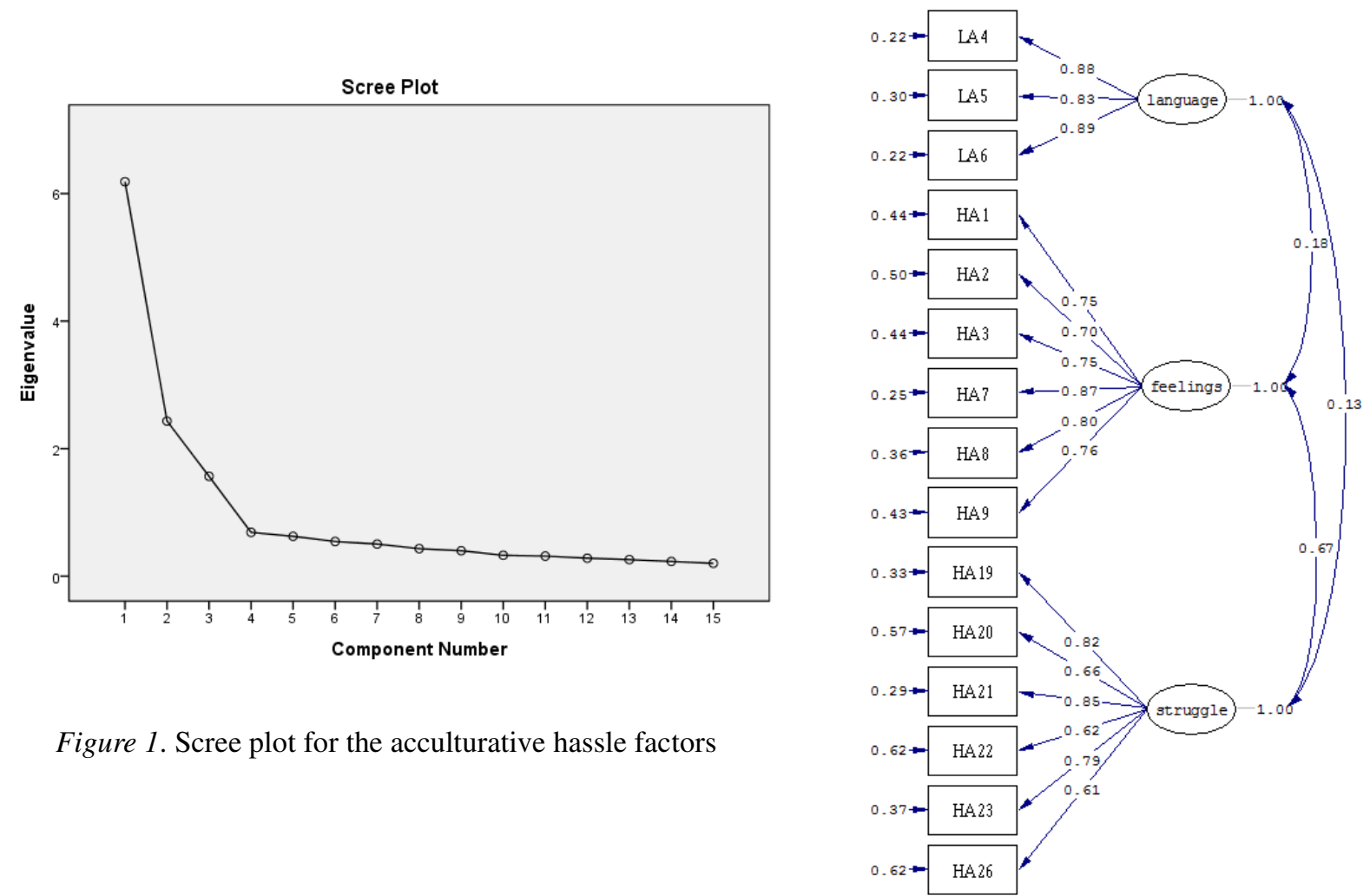

Chi-Square $=349.71, \mathrm{df}=87, \mathrm{P}$-value $=0.00000, \mathrm{RMSEA}=0.058$

Figure 2. SEM measurement model for the acculturative hassle factors

Table 5

Factor loading for the acculturative hassle survey $(N=888)$

\begin{tabular}{lccc}
\hline \multicolumn{1}{c}{ Items/Factors } & Adverse feelings & Struggles & Language difficulties \\
\hline Hassle_07 & .807 & .306 & .059 \\
Hassle_03 & .790 & .207 & .095 \\
Hassle_02 & .769 & .145 & .018 \\
Hassle_08 & .764 & .299 & .044 \\
Hassle_09 & .762 & .250 & .094 \\
Hassle_01 & .743 & .266 & .074 \\
\hline Hassle_21 & .260 & .828 & .050 \\
Hassle_23 & .298 & .763 & .067 \\
Hassle_19 & .308 & .762 & .103 \\
Hassle_20 & .136 & .734 & -.022 \\
Hassle_22 & .170 & .686 & .012 \\
Hassle_26 & .236 & .652 & -.006 \\
\hline Language_04 & .046 & .003 & .921 \\
Language_06 & .095 & .040 & .912 \\
Language_05 & .091 & .055 & .894 \\
\hline
\end{tabular}

Note. Extraction method: Principal Component Analysis, Rotation method: Varimax with Kaiser Normalization, Rotation converged in 5 iterations. 
Acculturative hassles and strategies: Relationship between study abroad related depression, anxiety, and stress

Table 6

Model fit for the acculturation hassle survey

\begin{tabular}{lc|lc|lc}
\hline Comparative fit index & Value & Absolute/predictive fit index & Value & Parsimonious fit index & Value \\
\hline NFI & .98 & Chi-square $\chi 2$ & 349.71 & PNFI & .81 \\
NNFI & .98 & GFI & .95 & PGFI & .69 \\
CFI & .98 & AGFI & .93 & CN & 312.25 \\
IFI & .98 & RMR & .045 & & .034 \\
RFI & .97 & SRMR & .058 & & \\
& & RMSEA & & \\
\hline
\end{tabular}

Table 7

Standardized and unstandardized coefficients for the acculturation hassle survey

\begin{tabular}{lllllll}
\hline Observed variable (item) & Latent construct (factor) & $\beta$ & error & $B$ & $S E$ & $T$ \\
\hline Hassle_07 & Adverse feelings & .87 & .25 & .88 & .03 & 31.73 \\
Hassle_03 & & .75 & .44 & .78 & .03 & 25.26 \\
Hassle_02 & & .70 & .50 & .67 & .03 & 23.33 \\
Hassle_08 & .80 & .36 & .88 & .03 & 27.97 \\
Hassle_09 & .76 & .43 & .79 & .03 & 25.79 \\
Hassle_01 & & .75 & .44 & .78 & .03 & 25.37 \\
\hline Hassle_21 & Struggles & .85 & .29 & .98 & .03 & 30.11 \\
Hassle_23 & & .79 & .37 & .88 & .03 & 27.41 \\
Hassle_19 & .82 & .33 & .92 & .03 & 28.69 \\
Hassle_20 & .66 & .57 & .84 & .04 & 21.09 \\
Hassle_22 & & .62 & .62 & .78 & .04 & 19.46 \\
Hassle_26 & & .61 & .62 & .72 & .04 & 19.37 \\
\hline Language_04 & & .83 & .22 & 1.17 & .04 & 32.06 \\
Language_06 & .89 & .30 & 1.06 & .03 & 32.21 \\
Language_05 & Communication difficulties & .83 & .22 & 1.13 & .04 & 29.56 \\
\hline
\end{tabular}

Note. T values are all significant.

Within the acculturative hassle factors adverse feelings are items related to the students' daily living, issues resulting with negative emotional feelings. Table 4 shows that the overall mean of the adverse feelings factor is 1.88 with the survey items using a 5 scale Likert scale denoting the degree of perceived relation to statement $(1=0 \%, 2=20 \%, 3=50 \%$., $4=80 \%$, and $5=100 \%)$. Hence, an overall average of 1.88 denotes that participants on average felt the adverse feelings barely around $20 \%$ of the time. As for the struggles, these are mostly the academic related hassles. Overall mean of the factor struggles is 2.42 denoting moderate academic related difficulties. However, the item not having enough sleep with a mean of 2.71 shows that more than half of the time, students are having difficulties with this issue. Lastly, communication difficulties are communication difficulties that students encounter daily with the highest overall mean of 2.57 implying also that almost half of the time, students are having these difficulties.

\subsection{Acculturative strategies}

The results of the revised 26 items EAAM were also encoded and analyzed through the use of the software SPSS. Data was first screened for univariate outliers and missing data imputed using the EM algorithm of SPSS (Graham, 2009; Weaver \& Maxwell, 2014). During the factor analysis procedures, a total of 5 items were eliminated from the 26 items revised EAAM survey. These items were deleted because they did not have a primary factor loading of .50 or above, and no cross-loading of .32 or above (Costello \& Osborne, 2005). Then after, the factorability of the remaining 21 items is tested under several criteria for factor analysis. First, the 21 items were checked for inter-correlation with at least one item of .30 or above. Second, the Kaiser-Meyer-Olkin value was computed to be .90 well above the acceptable value of .50 (Kaiser, 1974). Lastly, the Barlett's test of sphericity was computed to be at 10,649.36 with significant Chi-square $(p<.000)$ and a degrees freedom of 210.

The principal component analysis with varimax rotation was then conducted, while the eigenvalues were 
Ching, G. S., Chao, P.-C., \& Lien, W.-C.

computed to be greater than 1 (Costello \& Osborne, 2005). Three factors accounting for $67.08 \%$ of the total variances were computed. Each of the EAAM factors marginalization, separation, assimilation, and integration accounted for $27.56 \%, 14.91 \%, 14.26 \%$, and $10.35 \%$ of the variance respectively. A scree tests was also computed with the point of inflexion noted in Figure 3, further signifying the number of factors extracted from the items (Catell, 1966). Tables 8 show the various communalities of the items with values of greater than .400 (Worthington \& Whittaker, 2006), together with the Cronbach alpha reliabilities of the factors (.821 to .928; signifying highly reliable results), percent variance, overall means, and means and standard deviations of each of the items. While, Table 9 shows the various factor loading (including the cross-loading) of each of the items.

Table 8

Revised EAAM items $(N=888)$

\begin{tabular}{|c|c|c|c|}
\hline Factors/Items & Communalities & Mean & $S D$ \\
\hline Marginalization $(\alpha=.928,9$ items, $\%$ variance $=27.56)$ & & 1.60 & 0.71 \\
\hline Ma_04. I find it hard to communicate with anyone & .747 & 1.68 & 0.93 \\
\hline Ma_06. People find it hard to accept me & .747 & 1.52 & 0.80 \\
\hline Ma_05. I find it hard to make friends & .722 & 1.72 & 1.02 \\
\hline Ma_08. People have difficulty understanding me & 679 & 1.56 & 0.85 \\
\hline Ma_01. I find it difficult to socialize with anybody & 670 & 1.81 & 0.98 \\
\hline Ma_03. I think no one understands me & .640 & 1.63 & 0.96 \\
\hline Ma_09. I am uncomfortable when I am around other people & .579 & 1.55 & 0.85 \\
\hline Ma_02. I feel that nobody likes me & .542 & 1.50 & 0.83 \\
\hline Ma_07. I don't trust anyone & .469 & 1.46 & 0.83 \\
\hline Separation $(\alpha=.839,5$ items, $\%$ variance $=14.91)$ & & 3.07 & 0.94 \\
\hline Se_06. I feel relax when I am around people from my country & .758 & 3.32 & 1.16 \\
\hline Se_05. I prefer to go out with someone from my country & .714 & 3.04 & 1.24 \\
\hline $\begin{array}{l}\text { Se_03. I prefer going to gathering wherein most of the guest are from my } \\
\text { country }\end{array}$ & .611 & 2.89 & 1.22 \\
\hline $\begin{array}{l}\text { Se_08. I have more in common with my ethnic group than any other } \\
\text { ethnicity }\end{array}$ & .496 & 3.26 & 1.22 \\
\hline $\begin{array}{l}\text { Se_04. I feel that people who are from my country treat me as an equal, } \\
\text { more so than the local Taiwan people does }\end{array}$ & .513 & 2.83 & 1.18 \\
\hline Assimilation $(\alpha=.878,4$ items, $\%$ variance $=14.26)$ & & 3.14 & 0.94 \\
\hline As_04. I find it easier to communicate my feelings to local Taiwan people & .771 & 2.83 & 1.12 \\
\hline As_03. I feel that local Taiwan people understand me better & .747 & 2.84 & 1.06 \\
\hline As_05. I feel more comfortable socializing with local Taiwan people & .755 & 3.32 & 1.13 \\
\hline As_02. I get along better with local Taiwan people & .683 & 3.58 & 1.10 \\
\hline Integration $(\alpha=.821,3$ items, $\%$ variance $=10.35)$ & & 4.06 & 0.88 \\
\hline $\begin{array}{l}\text { In_02. I feel that both Taiwan friends and friends who are from my } \\
\text { country value me }\end{array}$ & .789 & 4.01 & 0.99 \\
\hline In_01. I have both Taiwan friends and friends who are from my country & .703 & 4.15 & 1.08 \\
\hline $\begin{array}{l}\text { In_03. I feel comfortable around Taiwan friends and friends who are from } \\
\text { my country }\end{array}$ & .750 & 4.01 & 0.98 \\
\hline
\end{tabular}

To further validate the revised EAAM survey, SEM was used. Figure 4 shows the measurement model of the revised EAAM survey with a Chi-square of 774.78 with $d f=183$, which is significant with $p<.000$ and a RMSEA value of .060 all of which are within the acceptable factor analysis values in SEM (Schreiber et al., 2006). Table 10 shows several comparative fit indices (including other indices), such as: Normed Fit Index (NFI) $=.96$, Non-Normed Fit Index $(\mathrm{NNFI})=.97$, Comparative Fit Index $(\mathrm{CFI})=.97$, Incremental Fit Index $(\mathrm{IFI})=.97$, and Relative Fit Index $($ RFI) = .96; all of which are within the acceptable values (Hu \& Bentler, 1999; MacCallum, Browne, \& Sugawara, 1996). Lastly, Table 11 shows the various standardized and unstandardized coefficients of the models, together with their corresponding $T$ values and measurement errors (Fornell \& Larcker, 1981), further describing fitness of the model. 

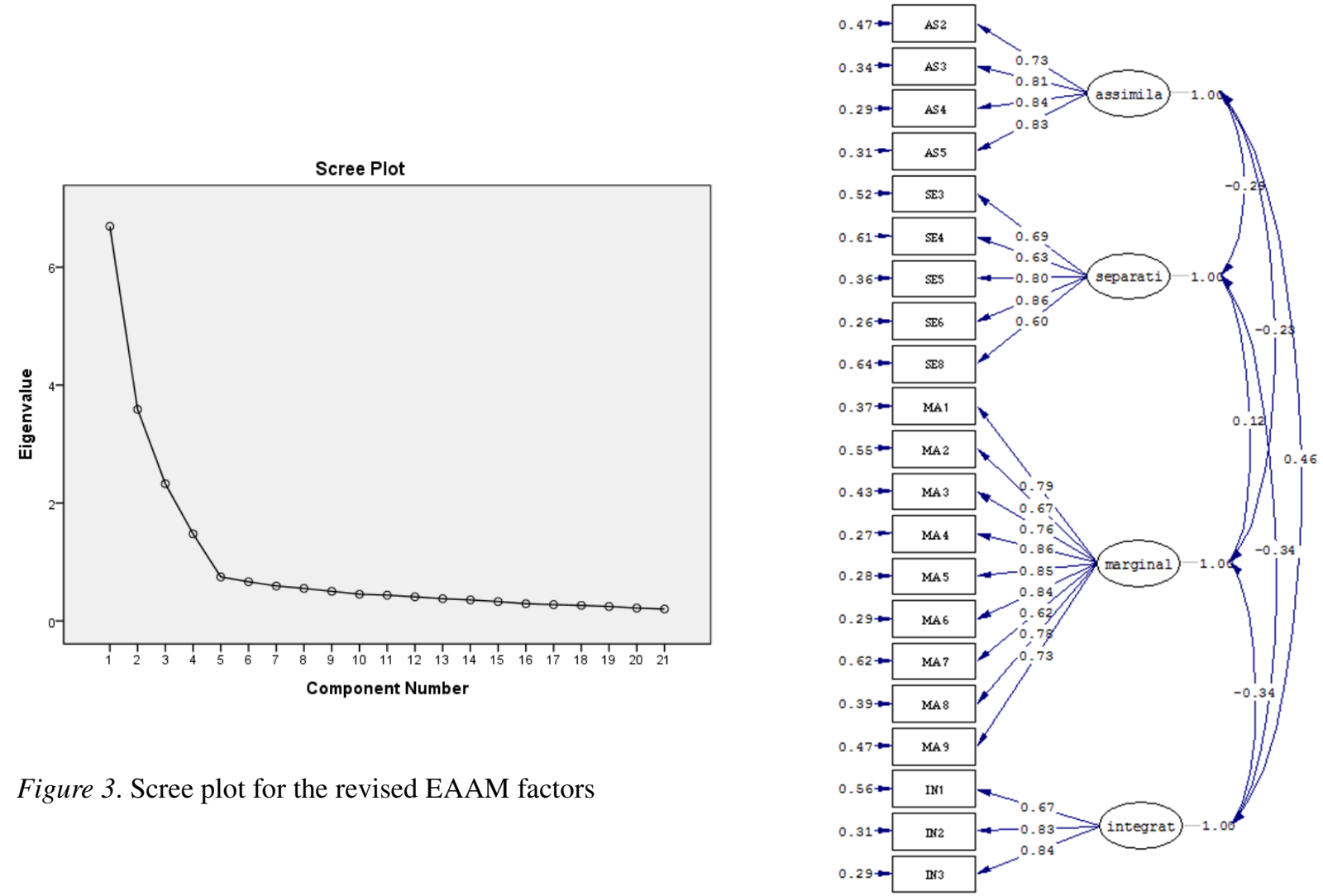

Chi-Square $=774.78, \mathrm{df}=183, \mathrm{P}-\mathrm{value}=0.00000, \mathrm{RMSEA}=0.060$

Figure 3. Scree plot for the revised EAAM factors

Table 9

Factor loading for the revised EAAM survey $(N=888)$

\begin{tabular}{lcccc}
\hline \multicolumn{1}{c}{ Items/Factors } & Marginalization & Separation & Assimilation & Integration \\
\hline Marginalization_04 & .858 & .020 & -.091 & -.037 \\
Marginalization_06 & .858 & .055 & -.087 & -.022 \\
Marginalization_05 & .838 & .056 & -.104 & -.081 \\
Marginalization_08 & .813 & .014 & -.080 & -.102 \\
Marginalization_01 & .806 & .060 & -.115 & -.055 \\
Marginalization_03 & .790 & .058 & -.007 & -.115 \\
Marginalization_09 & .748 & -.016 & -.025 & -.138 \\
Marginalization_02 & .733 & .062 & .003 & -.019 \\
Marginalization_07 & .655 & .029 & -.128 & -.150 \\
\hline Separation_06 & .061 & .848 & -.182 & -.049 \\
Separation_05 & .015 & .835 & -.020 & -.123 \\
Separation_03 & .009 & .779 & -.037 & -.047 \\
Separation_08 & .002 & .702 & -.046 & -.042 \\
Separation_04 & .130 & .687 & -.107 & -.118 \\
\hline Assimilation_04 & -.069 & -.172 & .852 & .103 \\
Assimilation_03 & -.050 & -.091 & .843 & .158 \\
Assimilation_05 & -.094 & -.124 & .837 & .174 \\
Assimilation_02 & -.182 & -.002 & .799 & .105 \\
\hline Integration_02 & -.172 & -.186 & .155 & .837 \\
Integration_01 & -.087 & -.026 & .141 & .821 \\
Integration_03 & -.208 & -.190 & .249 & .780 \\
\hline Notextacion
\end{tabular}

Note. Extraction method: Principal Component Analysis, Rotation method: Varimax with Kaiser Normalization, Rotation converged in 5 iterations. 
Ching, G. S., Chao, P.-C., \& Lien, W.-C.

Table 10

Model fit for the revised EAAM survey

\begin{tabular}{lc|lc|lc}
\hline Comparative fit index & Value & Absolute/predictive fit index & Value & Parsimonious fit index & Value \\
\hline NFI & .96 & Chi-square $\chi 2$ & 774.78 & PNFI & .84 \\
NNFI & .97 & GFI & .92 & PGFI & .73 \\
CFI & .97 & AGFI & .90 & CN & 275.12 \\
IFI & .97 & RMR & .045 & & \\
RFI & .96 & SRMR & .043 & & \\
& & RMSEA & .060 & & \\
\hline
\end{tabular}

Table 11

Standardized and unstandardized coefficients for the revised EAAM survey

\begin{tabular}{lcccccc}
\hline Observed variable (item) & Latent construct (factor) & $\beta$ & error & $B$ & $S E$ & $T$ \\
\hline Marginalization_04 & Marginalization & .86 & .27 & .79 & .03 & 31.36 \\
Marginalization_06 & & .84 & .29 & .67 & .02 & 30.72 \\
Marginalization_05 & .85 & .28 & .85 & .03 & 30.82 \\
Marginalization_08 & .78 & .39 & .66 & .02 & 27.38 \\
Marginalization_01 & .79 & .37 & .77 & .03 & 27.98 \\
Marginalization_03 & .76 & .43 & .72 & .03 & 26.15 \\
Marginalization_09 & .83 & .47 & .62 & .03 & 24.69 \\
Marginalization_02 & & .67 & .55 & .56 & .03 & 22.15 \\
Marginalization_07 & & .62 & .62 & .50 & .03 & 19.91 \\
\hline Separation_06 & & .86 & .26 & 1.00 & .03 & 29.97 \\
Separation_05 & Separation & .80 & .36 & .99 & .04 & 27.08 \\
Separation_03 & & .69 & .52 & .84 & .04 & 22.25 \\
Separation_08 & & .60 & .64 & .73 & .04 & 18.66 \\
Separation_04 & & .63 & .61 & .74 & .04 & 19.53 \\
\hline Assimilation_04 & & .84 & .29 & .94 & .03 & 29.60 \\
Assimilation_03 & & .81 & .34 & .87 & .03 & 28.24 \\
Assimilation_05 & Assimilation & .83 & .31 & .94 & .03 & 28.99 \\
Assimilation_02 & & .73 & .47 & .80 & .03 & 24.03 \\
\hline Integration_02 & & .83 & .31 & .83 & .03 & 27.60 \\
Integration_01 & & .67 & .56 & .72 & .03 & 20.87 \\
Integration_03 & Integration & .84 & .29 & .83 & .03 & 28.10 \\
\hline Non & & & & &
\end{tabular}

Note. T values are all significant.

Table 8 shows that among the four acculturation strategies, students are quite integrated with an overall mean of 4.06 denoting that most of them retained the best of their home and host cultures. All of the three items in the factor integration garnered a score of greater than 4 , which means that students felt the following I feel that both Taiwan friends and friends who are from my country value me, I have both Taiwan friends and friends who are from my country, and I feel comfortable around Taiwan friends and friends who are from my country around $80 \%$ of the time. These results are quite promising, since a key to successful integration is to break the ice and make friends with the host country's individuals. In addition, successful integration signifies that the students get to retain their home culture (including identity); therefore, cross-cultural sharing opportunity increases.

Interestingly, students are both somewhat separated with an overall mean of 3.07 and assimilated with an overall mean of 3.14, while marginalization with an overall mean of 1.60 signifying that students seldom felt that they are being marginalized; which is quite good. Highest marginalization item is I find it difficult to socialize with anybody with a mean of 1.81 and the lowest is I don't trust anyone with a mean of 1.46; these results show that students felt the marginalization items quite rarely (less than $20 \%$ of the time). Analysis for the acculturation strategies assimilation and separation will be more conclusive in the succeeding sections wherein comparison was made with the different student groups. 
Acculturative hassles and strategies: Relationship between study abroad related depression, anxiety, and stress

4.4 Students' depression, anxiety, and stress - comparative analysis among the different student groups

For the students' level of depression, anxiety, and stress, Table 10 shows that the overall mean for depression is 9.95 , anxiety is 8.86 , and stress is 7.26, which are somewhat above the normative scores for depression (6.34) and anxiety (4.70), while below the normative scores for stress (10.11) (Lovibond \& Lovibond, 1995). Further comparison among the various student groups shows that HKM students scored the highest, while MCS students scored the lowest in depression, anxiety, and stress. In addition, Table 11 shows a more detailed level of analysis and comparison. Levels of depression, anxiety, and stress are shown with further accuracy in terms of their severity. Overall Table 11 shows that $59.1 \%$ or 525 of the students have normal depression level, while the rest of the $40.9 \%$ suffers from mild to extreme. Note that there are around $9.1 \%(7 \%+2.1 \%)$ or 81 students are suffering from severe to extreme depressions, which are in need of much attention.

\section{Table 10}

Overall mean scores of various student groups $(N=888)$

\begin{tabular}{|c|c|c|c|c|c|c|}
\hline Variables/Student groups & & IS $(n=433)$ & $\operatorname{MCS}(n=270)$ & $\operatorname{OCS}(n=99)$ & $\mathrm{HKM}(n=86)$ & Total $(N=888)$ \\
\hline \multirow[t]{2}{*}{ Depression } & Mean & 10.93 & 7.31 & 11.18 & 11.90 & 9.95 \\
\hline & $S D$ & 7.08 & 5.67 & 6.85 & 8.24 & 7.00 \\
\hline \multirow[t]{2}{*}{ Anxiety } & Mean & 9.69 & 6.39 & 9.80 & 11.38 & 8.86 \\
\hline & $S D$ & 6.79 & 5.29 & 5.94 & 7.79 & 6.60 \\
\hline \multirow[t]{2}{*}{ Stress } & Mean & 7.82 & 5.21 & 8.30 & 9.72 & 7.26 \\
\hline & $S D$ & 7.20 & 5.25 & 7.00 & 8.56 & 6.94 \\
\hline \multirow[t]{2}{*}{ Assimilation } & Mean & 2.97 & 3.43 & 2.94 & 3.30 & 3.14 \\
\hline & $S D$ & 1.00 & 0.79 & 0.88 & 0.90 & 0.94 \\
\hline \multirow[t]{2}{*}{ Marginalization } & Mean & 1.64 & 1.40 & 1.83 & 1.81 & 1.60 \\
\hline & $S D$ & 0.72 & 0.57 & 0.84 & 0.76 & 0.71 \\
\hline \multirow{2}{*}{ Integration } & Mean & 4.15 & 3.97 & 3.96 & 3.97 & 4.06 \\
\hline & $S D$ & 0.87 & 0.86 & 0.85 & 0.94 & 0.88 \\
\hline \multirow[t]{2}{*}{ Separation } & Mean & 2.96 & 3.12 & 3.31 & 3.20 & 3.07 \\
\hline & $S D$ & 0.93 & 0.86 & 1.08 & 0.95 & 0.94 \\
\hline \multirow[t]{2}{*}{ Communication difficulties } & Mean & 3.09 & 2.16 & 1.79 & 2.19 & 2.57 \\
\hline & $S D$ & 1.30 & 0.72 & 0.79 & 0.95 & 1.18 \\
\hline \multirow[t]{2}{*}{ Adverse feelings } & Mean & 1.95 & 1.70 & 1.96 & 2.03 & 1.88 \\
\hline & $S D$ & 0.90 & 0.69 & 0.87 & 0.88 & 0.84 \\
\hline \multirow[t]{2}{*}{ Struggles } & Mean & 2.42 & 2.31 & 2.46 & 2.75 & 2.42 \\
\hline & $S D$ & 0.95 & 0.84 & 0.90 & 0.98 & 0.92 \\
\hline
\end{tabular}

Note. Values of interests are in bold face.

For the levels of anxiety, Table 11 shows that $51.4 \%$ or 456 students are within the normal level of anxiety, while the rest of the $48.6 \%$ are suffering from mild to extreme anxiety. More importantly, there are around $17.4 \%$ $(8.6 \%+8.6 \%)$ or 152 students who are suffering from severe to extreme anxiety. For the levels of stress, around $85.5 \%$ or 759 of the students have normal stress level, while the remaining $14.5 \%$ are suffering from mild to extreme stress. In addition, there are only around 3.2\% $(2.7 \%+0.5 \%)$ or 28 students who are suffering from severe to extreme stress. Further correlation analysis shown in Table 12 suggests that the levels of depression, anxiety, and stress are quite correlated with each other. Hence, this suggests that students with high levels of depression, anxiety, and stress might be the same group of individuals.

Table 12 shows the overall correlation of the DASS factors, acculturation strategies, and acculturative hassles. As mentioned earlier, results show that depression, anxiety, and stress are highly correlated with each other. This means that a depress student would very much likely to also be suffering from stress and anxiety. For the acculturation strategies, correlation analysis shows that assimilation is negatively correlated with the DASS factors; $r(886)=-.081 p<.016$ for depression, $r(886)=-.096 p<.004$ for anxiety, and $r(886)=-.069 p<.040$ for stress, while on the contrary marginalization is positively correlated with the DASS factors; $r(886)=.097 p$ $<.004$ for depression, $r(886)=.104 p<.002$ for anxiety, and $r(886)=.072 p<.031$ for stress. This means that a student who is highly assimilated will tend to experienced very low depression, anxiety, and stress. In addition, 
Ching, G. S., Chao, P.-C., \& Lien, W.-C.

separation is positively correlated with stress with $r(886)=.073 p<.029$, which suggests that separated students are also suffering from stress.

\section{Table 11}

Students' level of depression, anxiety, and stress $(N=888)$

\begin{tabular}{|c|c|c|c|c|c|c|c|c|c|c|c|c|c|c|c|}
\hline \multirow{2}{*}{$\begin{array}{l}\text { Student } \\
\text { groups }\end{array}$} & \multicolumn{15}{|c|}{ Depression } \\
\hline & $f$ & $\%$ within & Mean & $f$ & $\%$ within & Mean & $f$ & $\%$ within & Mean & $f$ & $\%$ within & Mean & $f$ & $\%$ within & Mean \\
\hline$\overline{\text { IS }}$ & 234 & $54.0 \%$ & 5.90 & 73 & $16.9 \%$ & 11.42 & 81 & $18.7 \%$ & 16.68 & 33 & $7.6 \%$ & 23.61 & 12 & $2.8 \%$ & 32.50 \\
\hline MCS & 199 & $73.7 \%$ & 4.52 & 32 & $11.9 \%$ & 11.34 & 27 & $10.0 \%$ & 15.81 & 11 & $4.1 \%$ & 23.09 & 1 & $0.4 \%$ & 32.00 \\
\hline OCS & 51 & $51.5 \%$ & 5.63 & 11 & $11.1 \%$ & 11.00 & 28 & $28.3 \%$ & 17.32 & 8 & $8.1 \%$ & 22.75 & 1 & $1.0 \%$ & 32.00 \\
\hline HKM & 41 & $47.7 \%$ & 4.90 & 11 & $12.8 \%$ & 11.64 & 19 & $22.1 \%$ & 16.42 & 10 & $11.6 \%$ & 23.10 & 5 & $5.8 \%$ & 30.20 \\
\hline $\begin{array}{r}\text { Total } \\
(\% \text { of } \mathrm{N}) \\
\end{array}$ & 525 & $59.1 \%$ & 5.27 & 127 & $14.3 \%$ & 11.39 & 155 & $17.5 \%$ & 16.61 & 62 & $7.0 \%$ & 23.32 & 19 & $2.1 \%$ & 31.84 \\
\hline \multirow{2}{*}{$\begin{array}{l}\text { Student } \\
\text { groups }\end{array}$} & \multicolumn{6}{|c|}{ Normal (0-7) } & \multicolumn{3}{|c|}{$\begin{array}{c}\text { Anxiety } \\
\text { Moderate (10-14) }\end{array}$} & \multicolumn{3}{|c|}{ Severe (15-19) } & \multicolumn{3}{|c|}{ Extreme $(20+)$} \\
\hline & $f$ & $\%$ within & Mean & $f$ & $\%$ within & Mean & $f$ & $\%$ within & Mean & $f$ & $\%$ within & Mean & $f$ & $\%$ within & Mean \\
\hline IS & 192 & $44.3 \%$ & 4.38 & 69 & $15.9 \%$ & 8.55 & 92 & $21.2 \%$ & 11.62 & 38 & $8.8 \%$ & 16.84 & 42 & $9.7 \%$ & 25.14 \\
\hline MCS & 192 & $71.1 \%$ & 3.71 & 27 & $10.0 \%$ & 8.52 & 29 & $10.7 \%$ & 11.93 & 13 & $4.8 \%$ & 16.77 & 9 & $3.3 \%$ & 24.11 \\
\hline OCS & 38 & $38.4 \%$ & 4.08 & 16 & $16.2 \%$ & 8.31 & 22 & $22.2 \%$ & 12.09 & 17 & $17.2 \%$ & 16.12 & 6 & $6.1 \%$ & 23.67 \\
\hline HKM & 34 & $39.5 \%$ & 4.15 & 12 & $14.0 \%$ & 8.50 & 13 & $15.1 \%$ & 12.46 & 8 & $9.3 \%$ & 17.00 & 19 & $22.1 \%$ & 23.05 \\
\hline $\begin{array}{r}\text { Total } \\
(\% \text { of } N) \\
\end{array}$ & 456 & $51.4 \%$ & 4.05 & 124 & $14.0 \%$ & 8.51 & 156 & $17.6 \%$ & 11.81 & 76 & $8.6 \%$ & 16.68 & 76 & $8.6 \%$ & 24.38 \\
\hline \multirow{2}{*}{$\begin{array}{l}\text { Student } \\
\text { groups }\end{array}$} & \multicolumn{6}{|c|}{ Normal (0-14) } & \multicolumn{3}{|c|}{$\begin{array}{c}\text { Stress } \\
\text { Moderate (19-25) }\end{array}$} & \multicolumn{3}{|c|}{ Severe (26-33) } & \multicolumn{3}{|c|}{ Extreme $(34+)$} \\
\hline & $f$ & $\%$ within & Mean & $f$ & $\%$ within & Mean & $f$ & $\%$ within & Mean & $f$ & $\%$ within & Mean & $f$ & $\%$ within & Mean \\
\hline$\overline{\mathrm{IS}}$ & 365 & $84.3 \%$ & 5.30 & 33 & $7.6 \%$ & 16.06 & 18 & $4.2 \%$ & 22.17 & 14 & $3.2 \%$ & 29.07 & 3 & $0.7 \%$ & 37.33 \\
\hline MCS & 251 & $93.0 \%$ & 4.08 & 10 & $3.7 \%$ & 17.00 & 7 & $2.6 \%$ & 22.29 & 2 & $0.7 \%$ & 29.50 & 0 & $0.0 \%$ & 0.00 \\
\hline OCS & 79 & $79.8 \%$ & 5.54 & 13 & $13.1 \%$ & 16.15 & 4 & $4.0 \%$ & 21.00 & 3 & $3.0 \%$ & 30.00 & 0 & $0.0 \%$ & 0.00 \\
\hline HKM & 64 & $74.4 \%$ & 5.34 & 5 & $5.8 \%$ & 16.20 & 11 & $12.8 \%$ & 21.18 & 5 & $5.8 \%$ & 28.80 & 1 & $1.2 \%$ & 36.00 \\
\hline $\begin{array}{r}\text { Total } \\
(\% \text { of } \mathrm{N})\end{array}$ & 759 & $85.5 \%$ & 4.93 & 61 & $\%$ & 16.25 & 40 & $\%$ & 80 & 24 & $2.7 \%$ & 29.17 & 4 & $0.5 \%$ & 37.00 \\
\hline
\end{tabular}

Note. Depression, anxiety, and stress levels are based on Lovibond and Lovibond's (1995) values. Values of interest are in bold face.

Table 12

Overall correlations $(N=888)$

\begin{tabular}{|c|c|c|c|c|c|c|c|c|c|c|c|}
\hline \multirow{3}{*}{ Variables } & & (1) & $(2)$ & (3) & (4) & $(5)$ & $(6)$ & $(7)$ & $(8)$ & $(9)$ & $(10)$ \\
\hline & Mean & 9.95 & 8.86 & 7.26 & 3.14 & 1.60 & 4.06 & 3.07 & 2.57 & 1.88 & 2.42 \\
\hline & $S D$ & 7.00 & 6.60 & 6.94 & 0.94 & 0.71 & 0.88 & 0.94 & 1.18 & 0.84 & 0.92 \\
\hline \multirow[t]{2}{*}{ Depression (1) } & $r$ & 1 & & & & & & & & & \\
\hline & $p$ & & & & & & & & & & \\
\hline \multirow[t]{2}{*}{ Anxiety (2) } & $r$ & .946 & 1 & & & & & & & & \\
\hline & $p$ & .000 & & & & & & & & & \\
\hline \multirow[t]{2}{*}{ Stress (3) } & $r$ & .896 & .914 & 1 & & & & & & & \\
\hline & $p$ & .000 & .000 & & & & & & & & \\
\hline \multirow[t]{2}{*}{ Assimilation (4) } & $r$ & -.081 & -.096 & -.069 & 1 & & & & & & \\
\hline & $p$ & .016 & .004 & .040 & & & & & & & \\
\hline \multirow[t]{2}{*}{ Marginalization (5) } & $r$ & .097 & .104 & .072 & -.223 & 1 & & & & & \\
\hline & $p$ & .004 & .002 & .031 & .000 & & & & & & \\
\hline \multirow[t]{2}{*}{ Integration (6) } & $r$ & -.034 & -.033 & -.040 & .391 & -.297 & 1 & & & & \\
\hline & $p$ & .316 & .323 & .229 & .000 & .000 & & & & & \\
\hline \multirow[t]{2}{*}{ Separation (7) } & $r$ & .054 & .054 & .073 & -.231 & .119 & -.272 & 1 & & & \\
\hline & $p$ & .107 & .109 & .029 & .000 & .000 & .000 & & & & \\
\hline \multirow[t]{2}{*}{ Communication difficulties (8) } & $r$ & .015 & .002 & -.004 & -.255 & .154 & -.091 & .071 & 1 & & \\
\hline & $p$ & .663 & .951 & .898 & .000 & .000 & .007 & .035 & & & \\
\hline \multirow[t]{2}{*}{ Adverse feelings (9) } & $r$ & .057 & .066 & .035 & -.155 & .552 & -.253 & .125 & .170 & 1 & \\
\hline & $p$ & .091 & .049 & .302 & .000 & .000 & .000 & .000 & .000 & & \\
\hline \multirow[t]{2}{*}{ Struggles (10) } & $r$ & .014 & .023 & .012 & -.168 & .467 & -.197 & .186 & .102 & .584 & 1 \\
\hline & $p$ & .667 & .493 & .722 & .000 & .000 & .000 & .000 & .002 & .000 & \\
\hline
\end{tabular}


Acculturative hassles and strategies: Relationship between study abroad related depression, anxiety, and stress

Further correlation analysis shows that assimilation is negatively correlated with marginalization with $r(886)$ $=-.223 p<.000$ and separation with $r(886)=-.231 p<.000$, while positively correlated with integration with $r(886)=.391 p<.000$ signifying that assimilated students are also somewhat integrated and vice versa. Further correlation trends among the various student groups also suggest such interpretation.

As for the acculturative hassle factors, the three factors are quite correlated with each other, which means these hassles are related with each other. Students who have communication trouble will probably be having adverse feelings and academic related struggles. Another interesting finding is that assimilation and integration is negatively correlated with the acculturative hassles, while marginalization and separation are positively correlated. These results further strengthen the assumption that marginalization and separation are somewhat caused by some or all of these acculturative hassles.

To further understand if the previous findings will also holds true when analysis is done with the different student groups; separate correlation analyses are achieved (see Tables 13 to 16). Table 13 shows the correlation result for the international students. Within the table, besides the acculturation strategies, similar trends hold true with a distinct finding of negative correlation between communication difficulties and anxiety with $r(886)=$ $-.103 p<.032$ suggesting that less communication difficulties for the international students tend to cause anxiety. Further analysis on this finding is urged, since communication is said to be a quite important factor in the acculturation process.

\section{Table 13}

Correlations for IS variables $(N=433)$

\begin{tabular}{|c|c|c|c|c|c|c|c|c|c|c|c|}
\hline \multirow{3}{*}{ Variables } & & (1) & (2) & (3) & (4) & (5) & (6) & (7) & $(8)$ & (9) & $(10)$ \\
\hline & Mean & 10.93 & 9.69 & 7.82 & 2.97 & 1.64 & 4.15 & 2.96 & 3.09 & 1.95 & 2.42 \\
\hline & $S D$ & 7.08 & 6.79 & 7.20 & 1.00 & 0.72 & 0.87 & 0.93 & 1.30 & 0.90 & 0.95 \\
\hline \multirow[t]{2}{*}{ Depression (1) } & $r$ & 1 & & & & & & & & & \\
\hline & $p$ & & & & & & & & & & \\
\hline \multirow[t]{2}{*}{ Anxiety (2) } & $r$ & .943 & 1 & & & & & & & & \\
\hline & $p$ & .000 & & & & & & & & & \\
\hline \multirow[t]{2}{*}{ Stress (3) } & $r$ & .899 & .918 & 1 & & & & & & & \\
\hline & $p$ & .000 & .000 & & & & & & & & \\
\hline \multirow[t]{2}{*}{ Assimilation (4) } & $r$ & -.019 & -.028 & -.022 & 1 & & & & & & \\
\hline & $p$ & .694 & .562 & .652 & & & & & & & \\
\hline \multirow[t]{2}{*}{ Marginalization (5) } & $r$ & .062 & .068 & .059 & -.190 & 1 & & & & & \\
\hline & $p$ & .195 & .159 & .223 & .000 & & & & & & \\
\hline \multirow[t]{2}{*}{ Integration (6) } & $r$ & -.041 & -.030 & -.045 & .397 & -.311 & 1 & & & & \\
\hline & $p$ & .393 & .529 & .347 & .000 & .000 & & & & & \\
\hline \multirow[t]{2}{*}{ Separation (7) } & $r$ & .038 & .034 & .033 & -.230 & .222 & -.263 & 1 & & & \\
\hline & $p$ & .436 & .485 & .498 & .000 & .000 & .000 & & & & \\
\hline \multirow[t]{2}{*}{ Communication difficulties (8) } & $r$ & -.081 & -.103 & -.082 & -.241 & .128 & -.127 & .148 & 1 & & \\
\hline & $p$ & .093 & .032 & .090 & .000 & .008 & .008 & .002 & & & \\
\hline \multirow[t]{2}{*}{ Adverse feelings (9) } & $r$ & .051 & .057 & .035 & -.098 & .541 & -.279 & .154 & .132 & 1 & \\
\hline & $p$ & .287 & .236 & .463 & .042 & .000 & .000 & .001 & .006 & & \\
\hline \multirow[t]{2}{*}{ Struggles (10) } & $r$ & .017 & .023 & .014 & -.171 & .511 & -.244 & .223 & .065 & .578 & 1 \\
\hline & $p$ & .717 & .634 & .773 & .000 & .000 & .000 & .000 & .180 & .000 & \\
\hline
\end{tabular}

Note. Significant correlations are in bold face

Table 14 shows the correlation results for the MCS, correlation trends are much similar with the previous overall findings with some minor differences. Similarly, Tables 15 and 16 also shows some similarity and differences. A very distinct consistency is that the DASS factors are quite correlated with each other, similarly the three acculturative hassles are also correlated with each other (except with the IS group). These findings continually suggest that the students' DASS are related with each other; indicating that when a student is stress out or suffering from anxiety, they tend to also be depressed. Furthermore, students who are having academic struggles also tend to be having communication difficulties and adverse feelings. Interestingly these acculturative hassles are not the cause for the students' depression and stress. Findings only suggests that 
Ching, G. S., Chao, P.-C., \& Lien, W.-C.

communication difficulties and anxiety are somewhat related. These findings all valid further analysis and interpretation, which is currently beyond the scope of the study.

\section{Table 14}

Correlations for MCS variables $(N=270)$

\begin{tabular}{|c|c|c|c|c|c|c|c|c|c|c|c|}
\hline \multirow{3}{*}{ Variables } & & (1) & (2) & (3) & (4) & (5) & (6) & (7) & (8) & (9) & (10) \\
\hline & Mean & 7.31 & 6.39 & 5.21 & 3.43 & 1.40 & 3.97 & 3.12 & 2.16 & 1.70 & 2.31 \\
\hline & $S D$ & 5.67 & 5.29 & 5.25 & 0.79 & 0.57 & 0.86 & 0.86 & 0.72 & 0.69 & 0.84 \\
\hline \multirow[t]{2}{*}{ Depression (1) } & $r$ & 1 & & & & & & & & & \\
\hline & $p$ & & & & & & & & & & \\
\hline \multirow[t]{2}{*}{ Anxiety (2) } & $r$ & .939 & 1 & & & & & & & & \\
\hline & $p$ & .000 & & & & & & & & & \\
\hline \multirow[t]{2}{*}{ Stress (3) } & $r$ & .892 & .889 & 1 & & & & & & & \\
\hline & $p$ & .000 & .000 & & & & & & & & \\
\hline \multirow[t]{2}{*}{ Assimilation (4) } & $r$ & -.058 & -.103 & -.079 & 1 & & & & & & \\
\hline & $p$ & .340 & .090 & .196 & & & & & & & \\
\hline \multirow[t]{2}{*}{ Marginalization (5) } & $r$ & .122 & .131 & .087 & -.213 & 1 & & & & & \\
\hline & $p$ & .046 & .031 & .152 & .000 & & & & & & \\
\hline \multirow[t]{2}{*}{ Integration (6) } & $r$ & -.083 & -.078 & -.044 & .396 & -.294 & 1 & & & & \\
\hline & $p$ & .175 & .201 & .467 & .000 & .000 & & & & & \\
\hline \multirow[t]{2}{*}{ Separation (7) } & $r$ & .104 & .099 & .151 & -.213 & -.011 & -.228 & 1 & & & \\
\hline & $p$ & .089 & .106 & .013 & .000 & .856 & .000 & & & & \\
\hline \multirow[t]{2}{*}{ Communication difficulties (8) } & $r$ & .045 & .049 & .040 & -.149 & .194 & -.124 & .139 & 1 & & \\
\hline & $p$ & .463 & .419 & .511 & .015 & .001 & .041 & .023 & & & \\
\hline \multirow[t]{2}{*}{ Adverse feelings (9) } & $r$ & .059 & .066 & .049 & -.156 & .579 & -.212 & .059 & .140 & 1 & \\
\hline & $p$ & .332 & .282 & .419 & .010 & .000 & .000 & .335 & .021 & & \\
\hline \multirow[t]{2}{*}{ Struggles (10) } & $r$ & -.019 & -.005 & .032 & -.122 & .336 & -.072 & .106 & .137 & .503 & 1 \\
\hline & $p$ & .757 & .937 & .597 & .045 & .000 & .236 & .082 & .025 & .000 & \\
\hline
\end{tabular}

\section{Table 15}

Correlations for OCS variables $(n=99)$

\begin{tabular}{|c|c|c|c|c|c|c|c|c|c|c|c|}
\hline \multirow{3}{*}{ Variables } & & (1) & (2) & (3) & (4) & (5) & (6) & $(7)$ & $(8)$ & (9) & (10) \\
\hline & Mean & 11.18 & 9.80 & 8.30 & 2.94 & 1.83 & 3.96 & 3.31 & 1.79 & 1.96 & 2.46 \\
\hline & $S D$ & 6.85 & 5.94 & 7.00 & 0.88 & 0.84 & 0.85 & 1.08 & 0.79 & 0.87 & 0.90 \\
\hline \multirow[t]{2}{*}{ Depression (1) } & $r$ & 1 & & & & & & & & & \\
\hline & $p$ & & & & & & & & & & \\
\hline \multirow[t]{2}{*}{ Anxiety (2) } & $r$ & .931 & 1 & & & & & & & & \\
\hline & $p$ & .000 & & & & & & & & & \\
\hline \multirow[t]{2}{*}{ Stress (3) } & $r$ & .867 & .903 & 1 & & & & & & & \\
\hline & $p$ & .000 & .000 & & & & & & & & \\
\hline \multirow[t]{2}{*}{ Assimilation (4) } & $r$ & -.126 & -.118 & -.152 & 1 & & & & & & \\
\hline & $p$ & .213 & .245 & .134 & & & & & & & \\
\hline \multirow[t]{2}{*}{ Marginalization (5) } & $r$ & .032 & .027 & .013 & -.330 & 1 & & & & & \\
\hline & $p$ & .753 & .794 & .901 & .001 & & & & & & \\
\hline \multirow[t]{2}{*}{ Integration (6) } & $r$ & -.029 & -.012 & -.052 & .522 & -.402 & 1 & & & & \\
\hline & $p$ & .777 & .902 & .610 & .000 & .000 & & & & & \\
\hline \multirow[t]{2}{*}{ Separation (7) } & $r$ & .013 & .014 & .081 & -.368 & .052 & -.281 & 1 & & & \\
\hline & $p$ & .897 & .894 & .426 & .000 & .610 & .005 & & & & \\
\hline \multirow[t]{2}{*}{ Communication difficulties (8) } & $r$ & .066 & .046 & .097 & -.310 & .262 & -.227 & .054 & 1 & & \\
\hline & $p$ & .516 & .650 & .342 & .002 & .009 & .024 & .597 & & & \\
\hline \multirow[t]{2}{*}{ Adverse feelings (9) } & $r$ & -.019 & -.016 & -.021 & -.166 & .466 & -.314 & .084 & .302 & 1 & \\
\hline & $p$ & .848 & .878 & .839 & .102 & .000 & .002 & .409 & .002 & & \\
\hline \multirow[t]{2}{*}{ Struggles (10) } & $r$ & .009 & -.004 & -.064 & -.259 & .523 & -.352 & .233 & .350 & .662 & 1 \\
\hline & $p$ & .931 & .967 & .532 & .010 & .000 & .000 & .021 & .000 & .000 & \\
\hline
\end{tabular}

Note. Significant correlations are in bold face 
Acculturative hassles and strategies: Relationship between study abroad related depression, anxiety, and stress

\section{Table 16}

Correlations for HKM variables $(n=86)$

\begin{tabular}{|c|c|c|c|c|c|c|c|c|c|c|c|}
\hline \multirow{3}{*}{ Variables } & & $(1)$ & $(2)$ & (3) & (4) & $(5)$ & (6) & (7) & $(8)$ & $(9)$ & $(10)$ \\
\hline & $\overline{\text { Mean }}$ & 11.90 & 11.38 & 9.72 & 3.30 & 1.81 & 3.97 & 3.20 & 2.19 & 2.03 & 2.75 \\
\hline & $S D$ & 8.24 & 7.79 & 8.56 & 0.90 & 0.76 & 0.94 & 0.95 & 0.95 & 0.88 & 0.98 \\
\hline \multirow[t]{2}{*}{ Depression (1) } & $r$ & 1 & & & & & & & & & \\
\hline & $p$ & & & & & & & & & & \\
\hline \multirow[t]{2}{*}{ Anxiety (2) } & $r$ & .962 & 1 & & & & & & & & \\
\hline & $p$ & .000 & & & & & & & & & \\
\hline \multirow[t]{2}{*}{ Stress (3) } & $r$ & .899 & .922 & 1 & & & & & & & \\
\hline & $p$ & .000 & .000 & & & & & & & & \\
\hline \multirow[t]{2}{*}{ Assimilation (4) } & $r$ & .014 & -.050 & .058 & 1 & & & & & & \\
\hline & $p$ & .897 & .647 & .595 & & & & & & & \\
\hline \multirow[t]{2}{*}{ Marginalization (5) } & $r$ & -.099 & -.081 & -.140 & -.060 & 1 & & & & & \\
\hline & $p$ & .364 & .458 & .198 & .581 & & & & & & \\
\hline \multirow[t]{2}{*}{ Integration (6) } & $r$ & -.034 & -.086 & -.076 & .542 & -.251 & 1 & & & & \\
\hline & $p$ & .756 & .431 & .487 & .000 & .020 & & & & & \\
\hline \multirow[t]{2}{*}{ Separation (7) } & $r$ & .142 & .153 & .127 & -.331 & -.002 & -.339 & 1 & & & \\
\hline & $p$ & .192 & .158 & .244 & .002 & .988 & .001 & & & & \\
\hline \multirow[t]{2}{*}{ Communication difficulties (8) } & $r$ & -.017 & .044 & .019 & -.167 & .303 & -.368 & .240 & 1 & & \\
\hline & $p$ & .876 & .689 & .859 & .125 & .005 & .000 & .026 & & & \\
\hline \multirow[t]{2}{*}{ Adverse feelings (9) } & $r$ & -.145 & -.117 & -.175 & -.247 & .577 & -.285 & .246 & .279 & 1 & \\
\hline & $p$ & .184 & .284 & .108 & .022 & .000 & .008 & .022 & .009 & & \\
\hline \multirow[t]{2}{*}{ Struggles (10) } & $r$ & -.130 & -.127 & -.152 & -.165 & .407 & -.159 & .146 & .245 & .682 & 1 \\
\hline & $p$ & .233 & .245 & .163 & .129 & .000 & .144 & .181 & .023 & .000 & \\
\hline
\end{tabular}

Note. Significant correlations are in bold face

To better understand if gender is an issue among the various factors; t-Test was accomplished. Table 17 shows that there are significant gender differences among the students' assimilation with Eta squared computed to be .012 suggesting small effect size (Cohen, 1988). Similarly, integration and separation also have significant gender differences with small effect size, suggesting that although there are statistical differences among the male and female students; their explain ability is not that conclusive.

Table 17

Gender differences among the variables $(N=888)$

\begin{tabular}{|c|c|c|c|c|c|c|c|c|}
\hline Variables & Gender & Mean & $S D$ & $F$ & $t$ & $p$ & $M D$ & Eta squared \\
\hline \multirow[t]{2}{*}{ Depression } & Female & 9.62 & 6.78 & 1.35 & -1.50 & .135 & -0.70 & .003 \\
\hline & Male & 10.32 & 7.22 & & & & & \\
\hline \multirow[t]{2}{*}{ Anxiety } & Female & 8.64 & 6.51 & 0.09 & -1.03 & .301 & -0.46 & .001 \\
\hline & Male & 9.10 & 6.69 & & & & & \\
\hline \multirow[t]{2}{*}{ Stress } & Female & 7.04 & 6.82 & 1.14 & -1.00 & .317 & -0.47 & .001 \\
\hline & Male & 7.51 & 7.07 & & & & & \\
\hline \multirow[t]{2}{*}{ Assimilation } & Female & 3.04 & 0.96 & 2.24 & -3.34 & .001 & -0.21 & .012 \\
\hline & Male & 3.25 & 0.91 & & & & & \\
\hline \multirow[t]{2}{*}{ Marginalization } & Female & 1.59 & 0.72 & 0.93 & -0.45 & .653 & -0.02 & .000 \\
\hline & Male & 1.62 & 0.70 & & & & & \\
\hline \multirow{2}{*}{ Integration } & Female & 3.93 & 0.93 & 12.83 & -4.65 & .000 & -0.27 & .024 \\
\hline & Male & 4.20 & 0.79 & & & & & \\
\hline \multirow[t]{2}{*}{ Separation } & Female & 3.13 & 0.96 & 3.07 & 2.13 & .033 & 0.13 & .005 \\
\hline & Male & 3.00 & 0.91 & & & & & \\
\hline \multirow[t]{2}{*}{ Communication difficulties } & Female & 2.56 & 1.17 & 0.60 & -0.20 & .840 & -0.02 & .000 \\
\hline & Male & 2.58 & 1.20 & & & & & \\
\hline \multirow[t]{2}{*}{ Adverse feelings } & Female & 1.88 & 0.82 & 0.68 & -0.07 & .947 & 0.00 & .000 \\
\hline & Male & 1.88 & 0.87 & & & & & \\
\hline \multirow[t]{2}{*}{ Struggles } & Female & 2.43 & 0.90 & 0.07 & 0.38 & .708 & 0.02 & .000 \\
\hline & Male & 2.41 & 0.95 & & & & & \\
\hline
\end{tabular}

Note. Significant gender differences are in bold face. $\mathrm{df}=886$, female $=461$, male $=427$ 
Table 17 also shows that gender is not an issue for the students' level of depression, anxiety, and stress. Similarly, acculturative hassles are not gender dependent. These means no matter what gender, students suffers from various hassles and emotional health issues. As for the effect of previous study abroad experiences, Table 18 shows that in general there are no significant differences among the various variables except for separation and communication difficulties. Results show that student who does not have previous study abroad experiences would tend to be more separated with Eta squared of .007 suggesting small effect (Cohen, 1988). While interestingly those who have previous study abroad experiences tend to have more communication difficulties with Eta squared of .013 also suggesting small effect (Cohen, 1988).

\section{Table 18}

Difference between students who have previous study abroad experiences $(N=888)$

\begin{tabular}{|c|c|c|c|c|c|c|c|c|}
\hline Variables & Previous experience & Mean & $S D$ & $F$ & $t$ & $p$ & $M D$ & Eta squared \\
\hline \multirow[t]{2}{*}{ Depression } & No & 9.83 & 7.11 & 2.63 & -0.99 & .321 & -0.56 & .001 \\
\hline & Yes & 10.39 & 6.60 & & & & & \\
\hline \multirow[t]{2}{*}{ Anxiety } & No & 8.84 & 6.72 & 4.58 & -0.15 & .877 & -0.08 & .000 \\
\hline & Yes & 8.92 & 6.18 & & & & & \\
\hline \multirow[t]{2}{*}{ Stress } & No & 7.18 & 7.00 & 0.23 & -0.67 & .502 & -0.38 & .001 \\
\hline & Yes & 7.56 & 6.74 & & & & & \\
\hline \multirow[t]{2}{*}{ Assimilation } & No & 3.14 & 0.93 & 1.93 & -0.02 & .982 & 0.00 & .000 \\
\hline & Yes & 3.14 & 0.99 & & & & & \\
\hline \multirow[t]{2}{*}{ Marginalization } & No & 1.58 & 0.68 & 5.20 & -1.75 & .080 & -0.10 & .003 \\
\hline & Yes & 1.68 & 0.80 & & & & & \\
\hline \multirow[t]{2}{*}{ Integration } & No & 4.06 & 0.87 & 0.04 & -0.09 & .927 & -0.01 & .000 \\
\hline & Yes & 4.06 & 0.89 & & & & & \\
\hline \multirow[t]{2}{*}{ Separation } & No & 3.11 & 0.93 & 0.06 & 2.51 & .012 & 0.19 & .007 \\
\hline & Yes & 2.92 & 0.95 & & & & & \\
\hline \multirow[t]{2}{*}{ Communication difficulties } & No & 2.50 & 1.15 & 3.75 & -3.46 & .001 & -0.33 & .013 \\
\hline & Yes & 2.83 & 1.25 & & & & & \\
\hline \multirow[t]{2}{*}{ Adverse feelings } & No & 1.87 & 0.84 & 0.03 & -0.82 & .412 & -0.06 & .001 \\
\hline & Yes & 1.93 & 0.87 & & & & & \\
\hline \multirow[t]{2}{*}{ Struggles } & No & 2.44 & 0.91 & 0.98 & 0.77 & .443 & 0.06 & .001 \\
\hline & Yes & 2.38 & 0.95 & & & & & \\
\hline
\end{tabular}

Note. Significant differences are in bold face. $\mathrm{df}=886$, yes $=198$, no $=690$

For the differences among the students who are enrolled within a degree seeking program or not, Table 19 shows that besides assimilation, separation, and the acculturative hassles communication difficulties, the rests of the variables have all significant differences with Eta squared .005 to .018; suggesting small effect size. These results suggests that students who are in Taiwan for degree program tends to be suffering from the DASS factors and some acculturative hassles (academic related struggles and adverse feelings). Furthermore, these students tend to be more integrated, while some are marginalized. These findings seem to point out that duration of stay might be an important factor in the analysis.

Table 20 shows the correlation analysis for the various variables as compared with duration of stay (in months) and the students' level of Mandarin Chinese and English language proficiencies. For the effect of the duration of stay in Taiwan, Table 20 shows that duration of stay is positively correlated with the acculturation strategies of assimilation and integration, denoting that the longer a student stays in Taiwan the more they tend to be assimilated and integrated. In addition, duration of stay is negatively correlated with separation, denoting that the shorter you stay the more tendency of being separated. Interesting findings are the positive correlation between the acculturative hassles of adverse feelings and academic struggles, while negative correlation between communication difficulties. These all needs additional research and analysis in the future.

For the effect of the Chinese language competency levels, in general as a students' Chinese language improved they become more assimilated with $r(886)=.212 p<.000$; similarly, is that as the students' Chinese language improved the less they are having communication difficulties with $r(886)=-.619 p<.000$; which is 
Acculturative hassles and strategies: Relationship between study abroad related depression, anxiety, and stress quite natural. As for the effect of the English language competency levels, interesting findings also shows that the higher the students' language competency level the more they are integrated, and the less they are marginalized and separated. As mentioned before, these results are beyond the scope of the current paper. It is urged that future researchers dwell on the issues of English language competencies. More importantly, English language competency levels is positively correlated with communication difficulties with $r(886)=.081 p<.016$; which is quite understandable. While, academic struggles is negatively correlated with English language competencies with $r(886)=-.108 p<.001$; as with the lessons are mostly done in the Chinese language.

Table 19

Difference between students who are enrolled in a degree program $(N=888)$

\begin{tabular}{|c|c|c|c|c|c|c|c|c|}
\hline Variables & Degree seeking & Mean & $S D$ & $F$ & $t$ & $p$ & $M D$ & Eta squared \\
\hline \multirow[t]{2}{*}{ Depression } & No & 9.28 & 6.74 & 0.41 & -2.20 & .028 & -1.07 & .005 \\
\hline & Yes & 10.35 & 7.12 & & & & & \\
\hline \multirow[t]{2}{*}{ Anxiety } & No & 8.14 & 6.29 & 1.04 & -2.51 & .012 & -1.15 & .007 \\
\hline & Yes & 9.29 & 6.75 & & & & & \\
\hline \multirow[t]{2}{*}{ Stress } & No & 6.63 & 6.65 & 2.88 & -2.09 & .037 & -1.00 & .005 \\
\hline & Yes & 7.64 & 7.09 & & & & & \\
\hline \multirow[t]{2}{*}{ Assimilation } & No & 3.17 & 0.96 & 0.57 & 0.82 & .411 & 0.05 & .001 \\
\hline & Yes & 3.12 & 0.94 & & & & & \\
\hline \multirow[t]{2}{*}{ Marginalization } & No & 1.48 & 0.65 & 7.38 & -4.06 & .000 & -0.20 & .018 \\
\hline & Yes & 1.68 & 0.74 & & & & & \\
\hline \multirow[t]{2}{*}{ Integration } & No & 3.96 & 0.87 & 0.50 & -2.58 & .010 & -0.16 & .007 \\
\hline & Yes & 4.12 & 0.87 & & & & & \\
\hline \multirow[t]{2}{*}{ Separation } & No & 3.12 & 0.87 & 4.87 & 1.16 & .246 & 0.08 & .002 \\
\hline & Yes & 3.04 & 0.98 & & & & & \\
\hline \multirow[t]{2}{*}{ Communication difficulties } & No & 2.61 & 1.14 & 4.24 & 0.76 & .445 & 0.06 & .001 \\
\hline & Yes & 2.55 & 1.21 & & & & & \\
\hline \multirow[t]{2}{*}{ Adverse feelings } & No & 1.75 & 0.78 & 9.95 & -3.64 & .000 & -0.21 & .015 \\
\hline & Yes & 1.96 & 0.87 & & & & & \\
\hline \multirow[t]{2}{*}{ Struggles } & No & 2.26 & 0.89 & 1.10 & -4.00 & .000 & -0.25 & .018 \\
\hline & Yes & 2.52 & 0.92 & & & & & \\
\hline
\end{tabular}

Note. Significant differences are in bold face. $\mathrm{df}=886$, yes $=558, \mathrm{no}=330$

\section{Table 20}

Correlation analysis between Mandarin Chinese/English language competencies and duration of stay $(N=888)$

\begin{tabular}{|c|c|c|c|c|}
\hline Variables & & Mandarin Chinese level & English language level & Duration (in months) \\
\hline \multirow[t]{2}{*}{ Depress } & $r$ & -0.048 & 0.018 & 0.062 \\
\hline & $p$ & 0.157 & 0.584 & 0.066 \\
\hline \multirow{2}{*}{ Anxiety } & $r$ & -0.035 & 0.000 & 0.064 \\
\hline & $p$ & 0.295 & 0.990 & 0.055 \\
\hline \multirow[t]{2}{*}{ Stress } & $r$ & -0.007 & -0.003 & 0.027 \\
\hline & $p$ & 0.825 & 0.939 & 0.417 \\
\hline \multirow[t]{2}{*}{ Assimilation } & $r$ & 0.212 & -0.026 & 0.077 \\
\hline & $p$ & 0.000 & 0.442 & 0.021 \\
\hline \multirow[t]{2}{*}{ Marginalization } & $r$ & -0.048 & -0.139 & 0.045 \\
\hline & $p$ & 0.156 & 0.000 & 0.180 \\
\hline \multirow{2}{*}{ Integration } & $r$ & -0.054 & 0.137 & 0.117 \\
\hline & $p$ & 0.111 & 0.000 & 0.000 \\
\hline \multirow[t]{2}{*}{ Separation } & $r$ & 0.058 & -0.070 & -0.124 \\
\hline & $p$ & 0.084 & 0.036 & 0.000 \\
\hline \multirow[t]{2}{*}{ Communication difficulties } & $r$ & -0.619 & 0.081 & -0.114 \\
\hline & $p$ & 0.000 & 0.016 & 0.001 \\
\hline \multirow[t]{2}{*}{ Adverse feelings } & $r$ & -0.057 & -0.043 & 0.081 \\
\hline & $p$ & 0.089 & 0.203 & 0.016 \\
\hline \multirow[t]{2}{*}{ Struggles } & $r$ & 0.030 & -0.108 & 0.117 \\
\hline & $p$ & 0.377 & 0.001 & 0.000 \\
\hline
\end{tabular}


Ching, G. S., Chao, P.-C., \& Lien, W.-C.

Lastly, for the statistical analysis of the various student groups and the variables, an analysis of variances (ANOVA) is accomplished. Table 21 shows the ANOVA results with significant differences among all the variables between the four student groups. Eta squared values are from .011 to .190 suggesting small (.01 to .05) to moderate (.06 to .13) effect sizes (Cohen, 1988).

Table 21

ANOVA test between student groups $(N=888)$

\begin{tabular}{|c|c|c|c|c|c|c|c|c|c|}
\hline Variables/Student groups & & IS & MCS & OCS & HKM & $S S$ & $F$ & $p$ & Eta squared \\
\hline \multirow[t]{2}{*}{ Depression } & Mean & 10.93 & 7.31 & 11.18 & 11.90 & 2769.02 & 20.07 & .000 & .064 \\
\hline & $S D$ & 7.08 & 5.67 & 6.85 & 8.24 & & & & \\
\hline \multirow[t]{2}{*}{ IS } & $M D$ & & 3.62 & -0.25 & -0.96 & & & & \\
\hline & $p$ & & .000 & .988 & .626 & & & & \\
\hline \multirow[t]{2}{*}{ MCS } & $M D$ & & & -3.87 & -4.58 & & & & \\
\hline & $p$ & & & .000 & .000 & & & & \\
\hline \multirow[t]{2}{*}{ OCS } & $M D$ & & & & -0.71 & & & & \\
\hline & $p$ & & & & .892 & & & & \\
\hline \multirow[t]{2}{*}{ Anxiety } & Mean & 9.69 & 6.39 & 9.80 & 11.38 & 2585.54 & 21.14 & .000 & .067 \\
\hline & $S D$ & 6.79 & 5.29 & 5.94 & 7.79 & & & & \\
\hline \multirow[t]{2}{*}{ IS } & $M D$ & & 3.30 & -0.11 & -1.70 & & & & \\
\hline & $p$ & & .000 & .999 & .111 & & & & \\
\hline \multirow[t]{2}{*}{ MCS } & $M D$ & & & -3.41 & -5.00 & & & & \\
\hline & $p$ & & & .000 & .000 & & & & \\
\hline \multirow[t]{2}{*}{ OCS } & $M D$ & & & & -1.59 & & & & \\
\hline & $p$ & & & & .332 & & & & \\
\hline \multirow[t]{2}{*}{ Stress } & Mean & 7.82 & 5.21 & 8.30 & 9.72 & 1891.37 & 13.65 & .000 & .044 \\
\hline & $S D$ & 7.20 & 5.25 & 7.00 & 8.56 & & & & \\
\hline \multirow[t]{2}{*}{ IS } & $M D$ & & 2.60 & -0.49 & -1.91 & & & & \\
\hline & $p$ & & .000 & .918 & .083 & & & & \\
\hline \multirow[t]{2}{*}{ MCS } & $M D$ & & & -3.09 & -4.51 & & & & \\
\hline & $p$ & & & .001 & .000 & & & & \\
\hline \multirow[t]{2}{*}{ OCS } & $M D$ & & & & -1.42 & & & & \\
\hline & $p$ & & & & .490 & & & & \\
\hline \multirow[t]{2}{*}{ Assimilation } & Mean & 2.97 & 3.43 & 2.94 & 3.30 & 42.32 & 16.66 & .000 & .054 \\
\hline & $S D$ & 1.00 & 0.79 & 0.88 & 0.90 & & & & \\
\hline \multirow[t]{2}{*}{ IS } & $M D$ & & -0.47 & 0.03 & -0.33 & & & & \\
\hline & $p$ & & .000 & .992 & .013 & & & & \\
\hline \multirow[t]{2}{*}{ MCS } & $M D$ & & & 0.49 & 0.13 & & & & \\
\hline & $p$ & & & .000 & .637 & & & & \\
\hline \multirow[t]{2}{*}{ HKM } & $M D$ & & & & -0.36 & & & & \\
\hline & $p$ & & & & .040 & & & & \\
\hline Marginalization & Mean & 1.64 & 1.40 & 1.83 & 1.81 & 20.11 & 13.77 & .000 & .045 \\
\hline & $S D$ & 0.72 & 0.57 & 0.84 & 0.76 & & & & \\
\hline IS & $M D$ & & 0.24 & -0.19 & -0.17 & & & & \\
\hline & $p$ & & .000 & .062 & .173 & & & & \\
\hline MCS & $M D$ & & & -0.43 & -0.40 & & & & \\
\hline & $p$ & & & .000 & .000 & & & & \\
\hline OCS & $M D$ & & & & 0.03 & & & & \\
\hline & $p$ & & & & .995 & & & & \\
\hline Integration & Mean & 4.15 & 3.97 & 3.96 & 3.97 & 7.65 & 3.36 & .018 & .011 \\
\hline & $S D$ & 0.87 & 0.86 & 0.85 & 0.94 & & & & \\
\hline IS & $M D$ & & 0.18 & 0.20 & 0.18 & & & & \\
\hline & $p$ & & .038 & .175 & .275 & & & & \\
\hline MCS & $M D$ & & & 0.02 & 0.00 & & & & \\
\hline & $p$ & & & .998 & 1.000 & & & & \\
\hline OCS & $M D$ & & & & -0.01 & & & & \\
\hline & $p$ & & & & 1.000 & & & & \\
\hline Separation & Mean & 2.96 & 3.12 & 3.31 & 3.20 & 13.39 & 5.14 & .002 & .017 \\
\hline & $S D$ & 0.93 & 0.86 & 1.08 & 0.95 & & & & \\
\hline IS & $M D$ & & -0.16 & -0.35 & -0.25 & & & & \\
\hline & $p$ & & .106 & .004 & .107 & & & & \\
\hline MCS & $M D$ & & & -0.19 & -0.09 & & & & \\
\hline & $p$ & & & .326 & .881 & & & & \\
\hline OCS & $M D$ & & & & 0.10 & & & & \\
\hline & $p$ & & & & .885 & & & & \\
\hline
\end{tabular}


Acculturative hassles and strategies: Relationship between study abroad related depression, anxiety, and stress

Table 21 ... continued

\begin{tabular}{|c|c|c|c|c|c|c|c|c|c|}
\hline Variables/Student groups & & IS & MCS & OCS & HKM & $S S$ & $F$ & $p$ & Eta squared \\
\hline \multirow[t]{2}{*}{ Communication difficulties } & Mean & 3.09 & 2.16 & 1.79 & 2.19 & 235.34 & 69.05 & .000 & .190 \\
\hline & $S D$ & 1.30 & 0.72 & 0.79 & 0.95 & & & & \\
\hline \multirow[t]{2}{*}{ IS } & $M D$ & & 0.93 & 1.30 & 0.90 & & & & \\
\hline & $p$ & & .000 & .000 & .000 & & & & \\
\hline \multirow[t]{2}{*}{ MCS } & $M D$ & & & 0.37 & -0.03 & & & & \\
\hline & $p$ & & & .018 & .996 & & & & \\
\hline \multirow[t]{2}{*}{ OCS } & $M D$ & & & & -0.40 & & & & \\
\hline & $p$ & & & & .055 & & & & \\
\hline \multirow[t]{2}{*}{ Adverse feelings } & Mean & 1.95 & 1.70 & 1.96 & 2.03 & 13.54 & 6.45 & .000 & .021 \\
\hline & $S D$ & 0.90 & 0.69 & 0.87 & 0.88 & & & & \\
\hline \multirow[t]{2}{*}{ IS } & $M D$ & & 0.25 & -0.01 & -0.08 & & & & \\
\hline & $p$ & & .001 & 1.000 & .859 & & & & \\
\hline \multirow[t]{2}{*}{ MCS } & $M D$ & & & -0.26 & -0.33 & & & & \\
\hline & $p$ & & & .044 & .008 & & & & \\
\hline \multirow[t]{2}{*}{ OCS } & $M D$ & & & & -0.07 & & & & \\
\hline & $p$ & & & & .935 & & & & \\
\hline \multirow[t]{2}{*}{ Struggles } & Mean & 2.42 & 2.31 & 2.46 & 2.75 & 13.12 & 5.23 & .001 & .017 \\
\hline & $S D$ & 0.95 & 0.84 & 0.90 & 0.98 & & & & \\
\hline \multirow[t]{2}{*}{ IS } & $M D$ & & 0.11 & -0.05 & -0.33 & & & & \\
\hline & $p$ & & .403 & .970 & .011 & & & & \\
\hline \multirow[t]{2}{*}{ MCS } & $M D$ & & & -0.16 & -0.45 & & & & \\
\hline & $p$ & & & .467 & .001 & & & & \\
\hline \multirow[t]{2}{*}{ OCS } & $M D$ & & & & -0.29 & & & & \\
\hline & $p$ & & & & .140 & & & & \\
\hline
\end{tabular}

Table 21 shows that the HKM scored highest in the three DASS scales for depression, anxiety, and stress. In addition, OCS is the most marginalized and separated student group among the foreign students, while the MCS is the most assimilated. Surprisingly the international students are the most integrated, while they also seem to have the most communication difficulties, while all the students moderately struggles with their academic related hassles.

\section{Conclusions}

The current study attempts to clarify some important issues regarding the acculturation processes of foreign students studying in Taiwan. As with the majority of the results are quite understandable and followed the trend of most acculturation studies. However, some interesting findings have come up, such as the issues of language competencies with the students' perceived hassles. In general the current study hopes that the findings are able to help both school administrators and future researchers in better understanding the issues within the study abroad processes. In essence, these insights should be able to provide a clear big picture of the major similarities and differences among the four foreign student groups studying in Taiwan.

Acknowledgement: This work is supported in part by the Taiwan Ministry of Science and Technology under grant number NSC 102-2410-H-262-012-SS2. The authors are grateful to the anonymous reviewers for the valuable comments and suggestions that made the manuscript complete.

\section{References}

Barry, D. T. (2001). Development of a new scale for measuring acculturation: The East Asian Acculturation Measure (EAAM). Journal of Immigrant Health, 3(4), 193-197. http://dx.doi.org/10.1023/A:1012227611547

Berry, J. W. (1980). Acculturation as varieties of adaptation. In A. Padilla (Ed.), Acculturation: Theory, models 
and findings (pp. 9-25). Boulder: Westview.

Berry, J. W. (1997). Immigration, acculturation and adaptation. Applied Psychology, 45(5-68).

Berry, J. W. (2004). Acculturation. In C. Spielberger (Ed.), Encyclopedia of applied psychology (Vol. 1, pp. 27-34). Boston: Elsevier. http://dx.doi.org/10.1016/B0-12-657410-3/00384-6

Berry, J. W. (2005). Acculturation: Living successfully in two cultures. International Journal of Intercultural Relations, 29, 697-712. http://dx.doi.org/10.1016/j.ijintrel.2005.07.013

Catell, R. B. (1966). The scree test for number of factors. Multivariate Behavioral Research, 1, 245-276. http://dx.doi.org/10.1207/s15327906mbr0102_10

Chin, J. M.-C., \& Ching, G. S. (2009). Trends and indicators of Taiwan's higher education internationalization. The Asia-Pacific Education Researcher, 18(2), 185-203. http://dx.doi.org/10.3860/taper.v18i2.1322

Chin, J. M.-C., Wu, C.-T., \& Ching, G. S. (2012). Apple and oranges: Comparison of Taiwan higher education institutions' internationalization. International Journal of Research Studies in Education, 1(1), 3-22. http://dx.doi.org/10.5861/ijrse.2012.v1i2.24

Ching, G. S., \& Chin, J. M.-C. (2012). Managing higher education institution internationalization: Contemporary efforts of a university in Taiwan. International Journal of Research Studies in Management, 1(1), 3-16. http://dx.doi.org/10.5861/ijrsm.2012.v1i1.9

Ching, G. S., Lien, W.-C., \& Chao, P.-C. (2014). Developing a scale to measure the situational changes in short-term study abroad programs. International Journal of Research Studies in Education, 3(5), 53-71. http://dx.doi.org/10.5861/ijrse.2014.771

Cohen, J. (1988). Statistical power analysis for the behavioral sciences. Hillsdale, NJ: Erlbaum.

Cohen, L., Manion, L., \& Morrison, K. (2007). Research methods in education. New York: Routledge.

Costello, A. B., \& Osborne, J. W. (2005). Best practices in exploratory factor analysis: Four recommendations for getting the most from your analysis. Practical Assessment, Research \& Evaluation, 10(7), 1-9.

Crawford, J. R., \& Henry, J. D. (2003). The Depression Anxiety Stress Scales (DASS): Normative data and latent structure in a large non-clinical sample. British Journal of Clinical Psychology, 42, 111-131. http://dx.doi.org/10.1348/014466503321903544

Fornell, C., \& Larcker, D. (1981). Structural equation models with unobservable variables and measurement error. Journal of Marketing Research, 18(1), 39-50. http://dx.doi.org/10.2307/3151312

Glaser, B., \& Strauss, A. (1967). The discovery of grounded theory: Strategies for qualitative research. New York: Aldine De Gruyter.

Graham, J. W. (2009). Missing data analysis: Making it work in the real world. Annual Review of Psychology, 60, 549-576. http://dx.doi.org/10.1146/annurev.psych.58.110405.085530

Greatrex-White, S. (2008). Uncovering study abroad: Foreignness and its relevance to nurse education and cultural competence. Nurse Education Today, 28, 530-538. http://dx.doi.org/10.1016/j.nedt.2007.09.005

Hair, J. F., Jr., Black, B., Babin, B. J., Anderson, R. E., \& Tatham, R. L. (2005). Multivariate data analysis (6th ed.). Upper Saddle River, New Jersey: Prentice Hall.

Hu, L. T., \& Bentler, P. M. (1999). Cutoff criteria for fit indexes in covariance structure analysis: Conventional criteria versus new alternatives. Structural Equation Modeling, 6, 1-55. http://dx.doi.org/10.1080/10705519909540118

Hummer, J. F., Pedersen, E. R., Mirza, T., \& LaBrie, J. W. (2010). Factors associated with general and sexual alcohol-related consequences: An examination of college students while studying abroad. Journal of Student Affairs Research and Practice, 47(4), 421-438. http://dx.doi.org/10.2202/1949-6605.6134

Hunley, H. A. (2010). Students' functioning while studying abroad: The impact of psychological distress and loneliness. International Journal of Intercultural Relations, 34, 386-392. http://dx.doi.org/10.1016/j.ijintrel.2009.08.005

Kaiser, H. F. (1974). An index of factorial simplicity. Psychometrika, 39, 31-36. http://dx.doi.org/10.1007/BF02291575

Leung, M. (2013). Private universities that close must not ' profiteer'. Retrieved from http://www.universityworldnews.com/article.php?story=20131010135545261

Lovibond, S. H., \& Lovibond, P. F. (1995). Manual for the depression anxiety stress scale (2nd ed.). Sydney: 
Acculturative hassles and strategies: Relationship between study abroad related depression, anxiety, and stress

Psychology Foundation.

Lucas, J. (2009). Over-stressed, overwhelmed, and over here: Resident directors and the challenges of student mental health abroad. Frontiers: The interdisciplinary journal of study abroad, 18, 187-215.

MacCallum, R. C., Browne, M. W., \& Sugawara, H. M. (1996). Power analysis and determination of sample size for covariance structure modeling. Psychological Methods, 1, 130-149.

http://dx.doi.org/10.1037/1082-989X.1.2.130

Ministry of Education [MOE]. (2014). Admission information. Retrieved from http://english.moe.gov.tw/content.asp? $\mathrm{mp}=1 \&$ CuItem=14419

Muto, T., Hayes, S. C., \& Jeffcoat, T. (2011). The effectiveness of acceptance and commitment therapy bibliotherapy for enhancing the psychological health of Japanese college students living abroad. Behavior Therapy, 42, 323-335. http://dx.doi.org/10.1016/j.beth.2010.08.009

Organisation for Economic Co-operation and Development [OECD]. (2013). How many students study abroad and where do they go? In Education at a glance 2013: Highlights (pp. 32-33). Paris: OECD Publishing.

Paige, M. R. (1990). International students: Cross-cultural psychological perspectives. In R. W. Brislin (Ed.), Applied cross-cultural psychology (pp. 161-185). Newbury Park, CA: Sage. http://dx.doi.org/10.4135/9781483325392.n8

Pedersen, E. R., Larimer, M. E., \& Lee, C. M. (2010). When in Rome: Factors associated with changes in drinking behavior among American college students studying abroad. Psychology of Addictive Behaviors, 24(3), 535-540. http://dx.doi.org/10.1037/a0019863

Pedersen, E. R., Neighbors, C., Larimer, M. E., \& Lee, C. M. (2011). Measuring sojourner adjustment among American students studying abroad. International Journal of Intercultural Relations, 35, 881-889. http://dx.doi.org/10.1016/j.ijintrel.2011.06.003

Sam, D. L., \& Berry, J. W. (2010). Acculturation: When individuals and groups of different cultural backgrounds meet. Perspectives on Psychological Science, 5(4), 472-481. http://dx.doi.org/10.1177/1745691610373075

Sam, D. L., \& Berry, J. W. (Eds.). (2006). The Cambridge handbook of acculturation psychology. Cambridge, United Kingdom: Cambridge University Press. http://dx.doi.org/10.1017/CBO9780511489891

Schreiber, J. B., Stage, F. K., King, J., Nora, A., \& Barlow, E. A. (2006). Reporting structural equation modeling and confirmatory factor analysis results: A review. Journal of Educational Research, 99(6), 323-337. http://dx.doi.org/10.3200/JOER.99.6.323-338

Tajalli, P., Sobhi, A., \& Ganbaripanah, A. (2010). The relationship between daily hassles and social support on mental health of university students. Procedia Social and Behavioral Sciences, 5, 99-103. http://dx.doi.org/10.1016/j.sbspro.2010.07.058

Vande Berg, M., Connor-Linton, J., \& Paige, M. R. (2009). The Georgetown consortium project: Intervening in student learning abroad. Frontiers: The Interdisciplinary Journal of Study Abroad, 18, 1-75.

Ward, C. A., Bochner, S., \& Furnham, A. (2001). The psychology of culture shock (2nd ed.). NY: Routledge.

Weaver, B., \& Maxwell, H. (2014). Exploratory factor analysis and reliability analysis with missing data: A simple method for SPSS users. The Quantitative Methods for Psychology, 10(2), 143-152.

Worthington, R. L., \& Whittaker, T. A. (2006). Scale development research: A content analysis and recommendations for best practices. Counseling Psychologist, 34(2), 806-838. http://dx.doi.org/10.1177/0011000006288127

Yu, W., \& Wang, S. (2011). An Investigation into the acculturation strategies of Chinese students in Germany. Intercultural Communication Studies, 20(2), 190-210. 
Ching, G. S., Chao, P.-C., \& Lien, W.-C. 